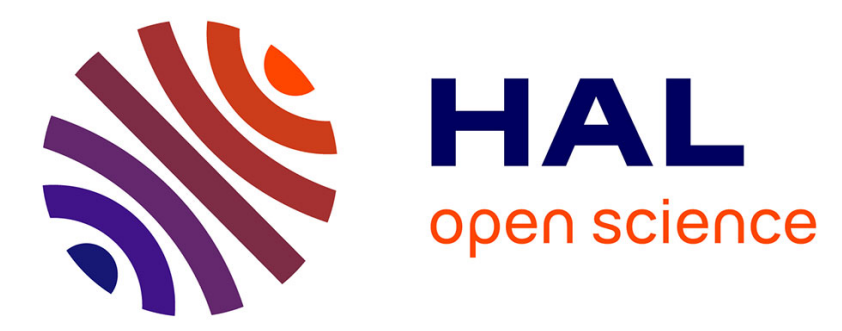

\title{
Composition of microbial communities in aerosol, snow and ice samples from remote glaciated areas (Antarctica, Alps, Andes)
}

\author{
J. Elster, Robert Delmas, J.-R. Petit, K. Reháková
}

\section{- To cite this version:}

J. Elster, Robert Delmas, J.-R. Petit, K. Reháková. Composition of microbial communities in aerosol, snow and ice samples from remote glaciated areas (Antarctica, Alps, Andes). Biogeosciences Discussions, 2007, 4 (3), pp.1779-1813. hal-00330243

\section{HAL Id: hal-00330243 \\ https://hal.science/hal-00330243}

Submitted on 19 Jun 2007

HAL is a multi-disciplinary open access archive for the deposit and dissemination of scientific research documents, whether they are published or not. The documents may come from teaching and research institutions in France or abroad, or from public or private research centers.
L'archive ouverte pluridisciplinaire HAL, est destinée au dépôt et à la diffusion de documents scientifiques de niveau recherche, publiés ou non, émanant des établissements d'enseignement et de recherche français ou étrangers, des laboratoires publics ou privés. 


\section{Composition of microbial communities in aerosol, snow and ice samples from remote glaciated areas (Antarctica, Alps, Andes)}

J. Elster ${ }^{1}$, R. J. Delmas ${ }^{2}$, J.-R. Petit ${ }^{2}$, and K. Řeháková ${ }^{1}$

${ }^{1}$ Institute of Botany, Academy of Sciences of the Czech Republic, Třeboň and Faculty of Biological Sciences, University of South Bohemia, České Budějovice, Czech Republic

${ }^{2}$ Laboratoire de Glaciologie et Géophysique de l'Environnement du CNRS, St Martin d'Hères, France

Received: 10 May 2007 - Accepted: 25 May 2007 - Published: 19 June 2007

Correspondence to: J. Elster (jelster@butbn.cas.cz)

Microbial

communities in aerosol, snow and ice

J. Elster et al.

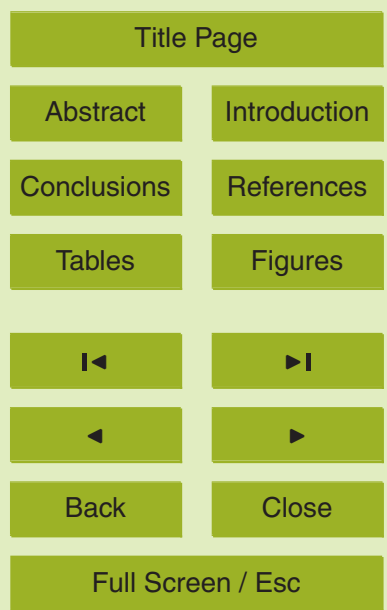

Printer-friendly Version

Interactive Discussion 


\section{Abstract}

Taxonomical and ecological analyses were performed on micro-autotrophs (cyanobacteria and algae together with remnants of diatom valves), micro-fungi (hyphae and spores), bacteria (rod, cocci and red clusters), yeast, and plant pollen extracted from 5 various samples: Alps snow (Mt. Blank area), Andean snow (Illimani, Bolivia), Antarctic aerosol filters (Dumont d'Urville, Terre Adélie), and Antarctic inland ice (Terre Adélie). Three methods for ice and snow sample's pre-concentration were tested (filtration, centrifugation and lyophilisation). Afterwards, cultivation methods for terrestrial, freshwater and marine microorganisms (micro-autotrophs and micro-fungi) were used in combination with liquid and solid media. The main goal of the study was to find out if micro-autotrophs are commonly transported by air masses, and later stored in snow and icecaps around the world. The most striking result of this study was the absence of culturable micro-autotrophs in all studied samples. However, an unusual culturable pigmented prokaryote was found in both alpine snow and aerosol samples. Analy15 ses of many samples and proper statistical analyses (PCA, RDA- Monte Carlo permutation tests) showed that studied treatments highly significantly differ in both microbial community and biotic remnants composition $F=9.33, p=0.001$. In addition, GLM showed that studied treatments highly significantly differ in numbers of categories of microorganisms and remnants of biological material $F=11.45, p=0.00005$. The Antarctic aerosol samples were characterised by having red clusters of bacteria, the unusual prokaryote and yeasts. The high mountain snow from the Alps and Andes contained much more culturable heterotrophs. The unusual prokaryote was very abundant, as were coccoid bacteria, red clusters of bacteria, as well as yeasts. The Antarctic ice samples were quite different. These samples had higher numbers of rod bacteria samples comprises two communities, without a sharp boundary between them: i) the first community includes ubiquitous organisms including contaminants, ii) the second community represents individuals frequently occurring in remote terrestrial cold or hot

BGD

4, 1779-1813, 2007

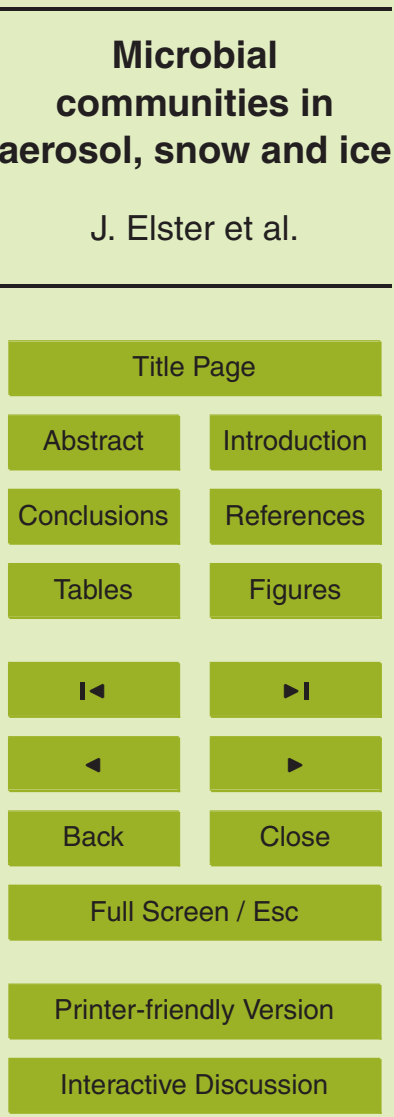

EGU 


\section{BGD}

\section{Introduction}

Snow accumulating on very high mountains and polar ice caps have build up environmental archives of great interest for paleoclimatic studies. By analyzing ice cores recovered from these areas, it has been possible to reconstruct past climate and related parameters such as the atmospheric content of trace gases, continental and marine aerosol species, extraterrestrial dust, and anthropogenic pollutants (Wagenbach, 1989; Delmas, 1992). Little work has been done on living (or dead) microorganisms. These are likely deposited together with particulate atmospheric impurities.

During the last decade, several papers (e.g. Gilichinsky et al., 1992; Broady, 1996; Elster et al., 1999; Schopf, 1999; Seckbach, 1999; Pedersen, 2001; Sattler et al., 2001) have shown that microbial life occurs everywhere on planet Earth, from the deep lithosphere, hydrosphere, and cryosphere - to well up into the atmosphere. It has been proposed that microorganisms living in hot and/or cold terrestrial deserts are especially important for the transmission of microbial genomes because of their special adaptations to be able to persist in uncommonly extreme and variable conditions (temperature, light intensity and spectral quality, water supply, desiccation, etc.) (Flechtner, 1999; Van Thielen and Garbary, 1999; Garty, 1999; Elster and Benson, 2004). Various microorganisms and the pollen of some plants have small dimensions (usually

less than $5 \mu \mathrm{m}$ in size) and therefore are easily transported around the world by air masses. Eventually, these wind-born particles are deposited on the ground, in either dry or wet form (Chalmers et al., 1996). Both the viable and dead cells, or their remnants, stored in the ice of continental icecaps and mountain glaciers have the potential to represent a historical record of the recent evolution of microbial life, as well as a record of the Earth's changing climate. In the wake of the recent discovery of the subglacial Antarctic Lake Vostok (Priscu et al., 1999; Siegert et al., 2001), and the hope of recovering water samples containing fossil living microorganisms, there is a growing
$4,1779-1813,2007$

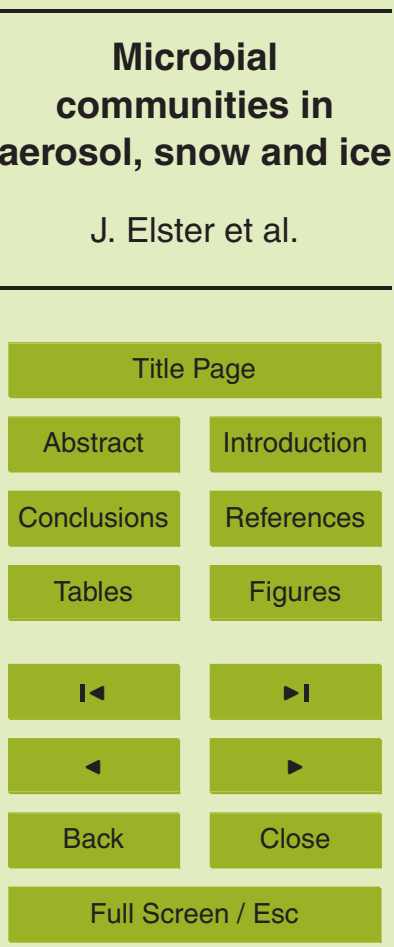

Printer-friendly Version

Interactive Discussion 
interest in investigating living species transported over large distances via air to remote cold glaciated regions.

In this study, we used samples from remote locations where measurements on the dry and wet deposition of inorganic and organic materials had previously been car5 ried out. The sites were all located in low temperature regions (Antarctica and very high elevation sites in the Alps and Andes). Moreover, a few inland Antarctic Ice-age ice samples have been investigated in order to evaluate the possible survival of living species in polar ice over time periods of centuries to several millennia.

We examined the microbial composition micro-autotrophs (cyanobacteria and algae 10 together with remnants of diatom valves), micro-fungi (hyphae and spores), bacteria (rod, cocci and red clusters), yeast, and plant pollen of remote aerosol, deposited snow, and ice - and evaluated the relevance of their distributions. Because the main goal of the study was to find out if cyanobacteria and algae are commonly transported by air masses, and then later stored in snow and icecaps around the world, the cultivation methods for terrestrial, freshwater and marine micro-autotrophs (and to a lesser extent for micro-fungi) were used. In addition, various methods for ice and snow sample's pre-concentration and various cultivation techniques were tested.

\section{Material and methods}

\subsection{Site and sample description}

20 Aerosol, snow, and ice samples were collected from remote glaciated areas in Antarctica, Alps, and the Andes. Aerosol samples were selected for this study from a set of filters collected between 1994 and 2000 at the coastal Antarctic Station Dumont d'Urville $\left(66^{\circ} 40^{\prime} \mathrm{S}, 140^{\circ} 01^{\prime} \mathrm{E}\right)$ for long-term atmospheric chemistry studies. This station is situated on a small island, a few hundred meters offshore of the mainland. Local meteorological conditions have been described by Périard and Pettré (1992) and König-Langlo et al. (1998). The main features of the chemical composition of the aerosol can be

BGD

4, 1779-1813, 2007
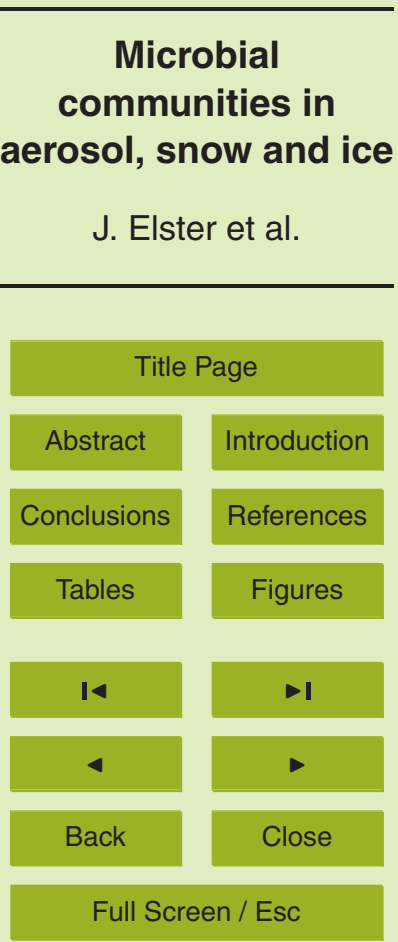

Printer-friendly Version

Interactive Discussion 
found in Wagenbach et al. (1998), Minikin et al. (1998), and Legrand et al. (1998).

For European alpine snow sampling, two snow pits were dug in the year 2000 at very high elevation sites in the Mt. Blank area of the Alps: one $(0.6 \mathrm{~m}$ deep) at Col du Midi (elev. 3532 m, 17 May); the other (2 m deep) at Col du Dome (elev. 4250 m, 31 August).

5 Snow collected from recent deposits contained several visible dust layers. This dust is known to be transported via wind to the Alps from the Sahara desert (Oeschger et al., 1977; Wagenbach, 1989; De Angelis and Gaudichet, 1991).

In the Andes, surface snow blocks were collected in 2000 at the summit of Nevado Illimani, Bolivia $\left(16^{\circ} 37^{\prime} \mathrm{S}, 67^{\circ} 46^{\prime} \mathrm{W}\right.$, Cordillera Real, elevation $6350 \mathrm{~m}$ ). The Bolivian 10 Andes are surrounded by the Altiplano, a high altitude desert (mean elevation: $3700 \mathrm{~m}$ a.s.l., Clapperton, 1993). This region, in particular, contains large salt flats called "salars" (Risacher, 1992), which are an important source of dust for the regional atmosphere during the dry season.

Antarctic ice samples were selected from two ice cores (D10 and Caroline, here15 after designated "CAR", recovered in 1978 and 1987, respectively) from Terre Adélie (East Antarctica). Note that the upper $20 \mathrm{~m}$ of the cores are firn (compacted snow), not ice. Twenty samples were from the $303 \mathrm{~m} \mathrm{D10}$ ice core recovered $5 \mathrm{~km}$ inland from the coast, close to the Dumont d'Urville station. The International Antarctic Glaciological Project (IAGP) flow line starting from D10 towards Dome $C$, is a region where the ice dynamics and dating have been studied in detail (Raynaud et al., 1979). From the surface, down to about $120 \mathrm{~m}$ ( 5 samples), the ice has a local origin. Thereafter, a decrease of the deuterium content is observed, due to the more inland origin of the snow. From 145 to $170 \mathrm{~m}$ ( 6 samples), the ice originates from 80 to $100 \mathrm{~km}$ inland. Below $210 \mathrm{~m}$ (9 samples), the ice originates more than $200 \mathrm{~km}$ inland and is about 18000 25 years old. Seven different levels (13 samples) have been selected along "CAR" ( $82 \mathrm{~m}$ in length), recovered at a distance of about $500 \mathrm{~m}$ from the coastline, in the same region as D10. There also, the ice dynamics are well documented (Yao et al., 1990). The upper $21 \mathrm{~m}$ of the record are consist of local precipitation (5 samples at $18.72-19.48 \mathrm{~m}$ ). Four samples, at $28.9-30.05 \mathrm{~m}$, and four at $41.8-42.6 \mathrm{~m}$ represent mid-Holocene (de-
BGD

4, 1779-1813, 2007

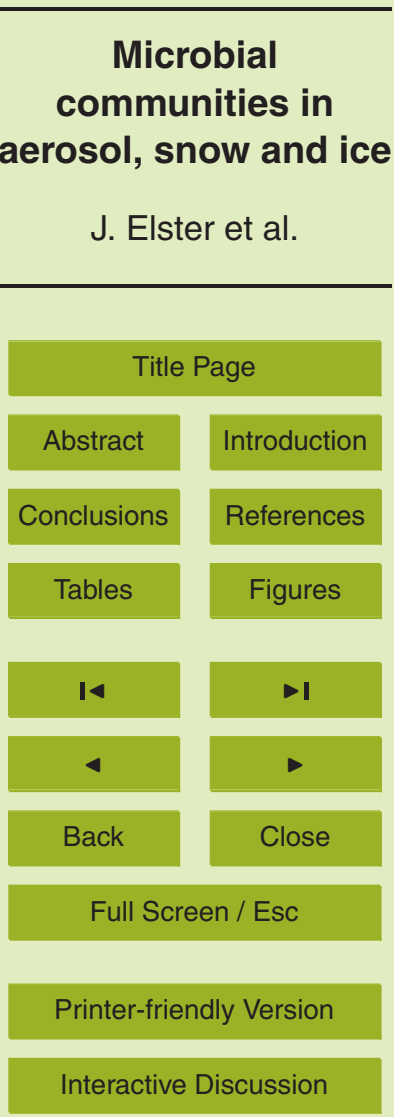

EGU 
posited 80-100 km inland) and LGM (Last Glacial Maximum) precipitation, respectively. LGM ice is known to have a high dust content (Yao et al., 1990).

All samples were collected using careful precautions in pre-cleaned glass vials (aerosol) and sealed plastic bags (snow and ice), respectively - and transported frozen 5 to the Laboratoire de Glaciologie et Géophysique de l'Environment (LGGE) in Grenoble, France and stored frozen until analysis. Samples were kept frozen (in temperatures between $-25^{\circ} \mathrm{C}$ to $-35^{\circ} \mathrm{C}$ ) during storage and transportation to protect viable cells against injuries performed by melting-freezing processes. Studied localities are located in elevation or on glaciers where no or very rare melting occur. Only snow10 ice sublimation occur here. In all localities cryophilic community development was not recorded.

\subsection{Experimental methods}

Three methods (filtration, centrifugation and lyophilisation) for ice and snow samples pre-concentration were tested. Afterwards, cultivation methods for terrestrial, freshwater and marine microorganisms (micro-autotrophs and micro-fungi) were used in combination with liquid and solid media. Taxa were examined using light, fluorescence, and electron microscopy. Culturable microorganisms (or their cell remnants) were placed in the following categories: a) cyanobacteria and non-diatom micro-algae, b) diatom valves and their segments, c) bacteria - coccoid, rod, and red clusters, d) fungi - spores and hyphae, e) yeast, and f) pollen.

\subsection{Aerosol sample collection and treatments}

All together, 13 Antarctic aerosol samples + blank were collected on Gelman Zefluor® filters ( $47 \mathrm{~mm}$ diameter, $0.5 \mu \mathrm{m}$ pore size) by drawing in air at a flow rate of $1.5 \mathrm{~m}^{3} \mathrm{~h}^{-1}$. The sampling interval was $20 \mathrm{~h}$ in summer (from November to February) and $40 \mathrm{~h}$ the rest of the year, which corresponds with 30 and $60 \mathrm{~m}^{3}$ of air, respectively. All devices used were washed three times with $18.2 \mathrm{M} \Omega \mathrm{cm}$ MilliQ® water, except for the filters.

BGD

4, 1779-1813, 2007

\section{Microbial}

communities in

aerosol, snow and ice

J. Elster et al.

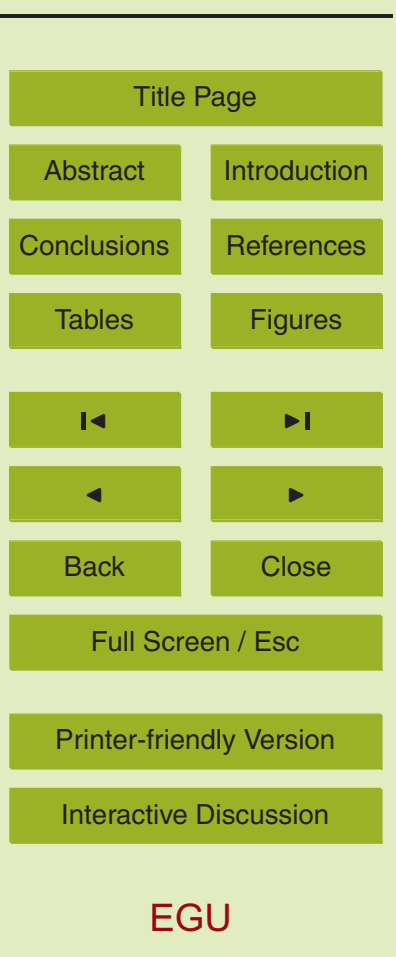


Pre and post sampling manipulations were made under a class 100 laminar flow hood. Filters were stored frozen at $-18^{\circ} \mathrm{C}$ in a polystyrene vial covered with Parafilm $\otimes$ just after collection. In 1999, the filters transferred frozen from LGGE in Grenoble to the Třeboň laboratory, were cut into (4) quarters for cultivation in 4 different liquid media - Z 5 (Staub 1961), BBM (Bold 1949), BG-11 (Bischoff and Bold, 1963), and seawater (ISO 10253 1995). Those filters transferred in 2001 , were cut into two parts, for cultivation in liquid media BBM and BG-11 only. Blanks for all treatments were empty vials or plastic bags of the same type used for collection of samples.

\subsection{Alpine sample preparation}

10 At the beginning of 2001, samples collected in the Alps (Col du Midi, 6 samples + blank; Col du Dome, 9 samples + blank) and the Andes (2 samples) were transferred frozen to the Trebon laboratory. All of these samples were cultivated in liquid, as well as in solid media (BG11, BBM).

\subsection{Ice sample preparation}

15 The ice samples from D10 and "CAR" were processed using two different procedures. In 1999, 26 ice samples and two blanks were prepared in the clean rooms of LGGE, Grenoble. Melt water samples $(47 \mathrm{ml})$ were filtered through Nuclepore $₫$ filters (diameter $13 \mathrm{~mm}$, porosity $0.2 \mu \mathrm{m}$ ). Filters were transported in cold and sterile conditions to Třebon. Every filter from this set was cut into four quarters. Before the filters were used in cultivation experiments, one quarter from each sample was in a clean air bench, directly observed in a light microscope. Further, the filter quarters were used for cultivation experiments in different liquid media (Z, BG11, BBM and sea water).

In 2000, 16 frozen ice samples were transferred by plane to the laboratory in Třeboň. The samples were then processed in a clean air bench under sterile conditions, using sterile glass vials. About $2 \mathrm{~cm}$ of each sample was removed from the surface by rinsing the ice with re-distilled water. Consequently, these samples were pre-concentrated

BGD

4, 1779-1813, 2007
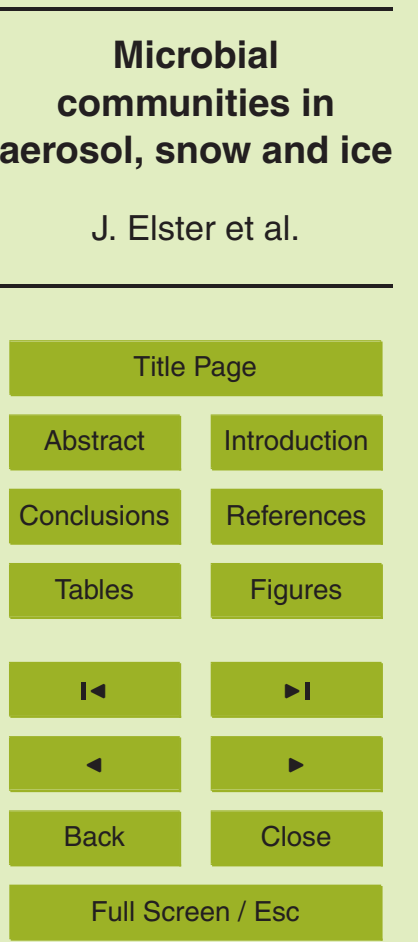

Printer-friendly Version

Interactive Discussion 
either by centrifugation (5 samples), or lyophilisation (11 samples).

The lyophilised samples were dried off at a temperature of $-40^{\circ} \mathrm{C}$ in a special sterile lyophilisation device (Lyovac GT2, Leybold-Heraeus, Germany). After this operation, glass vessels containing solid deposits were washed out using 10-15 ml re-distilled 5 water. Samples chosen for concentration by centrifugation were centrifuged in a volume of $10-15 \mathrm{ml}$. Both, lyophilised and centrifuged pre-concentrated samples were divided into thirds and cultivated in liquid Z, BG11 and BBM media.

\subsection{Cultivation and microscopy methods}

Cultivation experiments were carried out in sterile conditions at the Institute of Botany 10 (Culture Collection of Autotrophic Organisms), Treboň. Each sample was cultivated in a sterile glass bottle $(25 \mathrm{ml}$ in volume). The bottom of each sterile glass bottle was filled to a depth of one centimeter with glass beads (diameter $3 \mathrm{~mm}$ ). Cultivation media were: Z, BBM, BG-11, and seawater. Each glass bottle was filled with about $10 \mathrm{ml}$ of sterile medium. The solid media (1.5\% agar on Petri dishes) contained mineral nutrient 5 medium (BG11, BBM). Melted samples were spread on Petri dishes. All experimental glass bottles and Petri dishes were cultivated in an illuminated $\left(\sim 100 \mathrm{~W} \mathrm{~cm}^{2}\right)$ refrigerator (temperature $5-8^{\circ} \mathrm{C}$ ) with a light regime of $18 \mathrm{~h}$ of light, 2 hours of UV-B radiation (germicide lamp) and $4 \mathrm{~h}$ of dark. The germicide lamps sterilized the cultivation area repeatedly (UV-B light did not penetrate through the glass bottles). Experimental bot20 tles were shaken every 2-3 days. After 1 and 2 months of cultivation, the contents of experimental bottles were centrifuged and analyzed. Selected samples, where hyphae and spores of fungi occurred, were cultivated on Petri dishes with $2 \%$ malt-extract agar (MEA) with streptomycin and incubated in a thermostat (at $25^{\circ} \mathrm{C}$ in the dark) for $7-14$ days.

25 The 26 Antarctic ice samples ("CAR" and D10) proceeding 1999 were, additionally, observed directly in the light microscopy (LM - Olympus BX 60) for the presence of micro-autotrophs. The cultivation treatments, on liquid and agar, were also observed using light microscopy and photographic documentations were made of the observed

\section{BGD}

4, 1779-1813, 2007

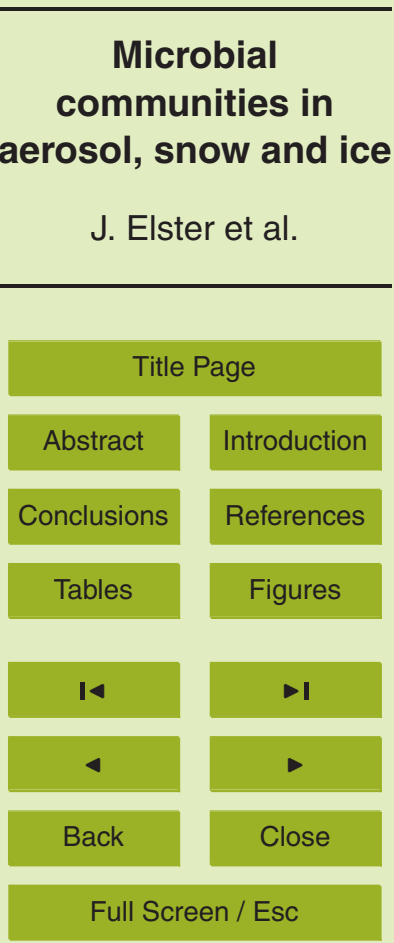

Printer-friendly Version

Interactive Discussion 
microorganisms. In all samples, the presence and/or absence of dust particles were estimated. This was done on basis of microscope visual field estimations of dust quantity. The microscope fields with dust were covered by tiny dense particles. In contrast, the fields without dust were free of particles - or the particles were bigger in size and 5 were associated into clumps. Because of this, only very raw estimates based only upon observer estimates were recorded, and no statistical tests were performed.

Selected samples with the unusual large-celled prokaryotic species were also studied by fluorescence - visualisation of DNA containing structures by fluorochrome DAPI (EFM - Olympus BX 60) (Zachleder and Cepák, 1987); and electron transmission mi10 croscopy (Jeol equipment JEM 1010).

\subsection{Statistical analysis}

The multidimensional data (presence of different organisms in aerosol, snow, and ice samples) formed the basis for an ordination analysis. Principal Component Analysis (PCA) was performed to visualize the data using CANOCO for Windows software pack15 age (Ter Braak and Šmilauer, 1998). In addition, the Redundancy Analysis (RDA) in CANOCO with Monte Carlo permutation test (1000 permutations) was used to test the differences among: i) aerosol, snow, and ice; ii) Caroline and D10 ice; iii) lyophilised, centrifuged and filtrated ice; iv) Alps and Andean snow; v) real and blank treatments; vi) cultivation media types - Z, BG 11, BBM, sea water; and vii) liquid - solid cultivation 20 media. In all particular tests only comparable data sets (with similar methodology of sampling, cultivation and analysis) were used. The resulting $\mathrm{F}-$ ratio in Monte Carlo permutation test has a similar meaning as the $F$ - value in ANOVA of the regression model, and the Monte Carlo permutation test is used in an analogous way (Lepš and Šmilauer, 2003).

$25 \quad$ Generalized Linear Models (GLM) (McCullagh and Nelder, 1989) were used to test the differences in numbers of categories of microorganisms and remnants of biological material in analysed samples.

\section{BGD}

4, 1779-1813, 2007
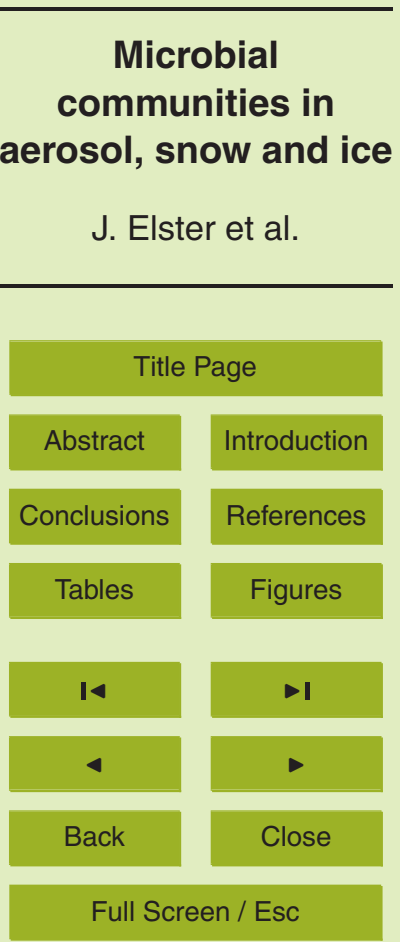

Printer-friendly Version

Interactive Discussion 


\section{Results}

\subsection{Absence of photoautotrophs}

The most striking result of this study was the absence of culturable prokaryotic and eukaryotic micro-algae. Very rarely found, were cyanobacteria resembling colonies 5 of Merismopedia spp. (in the Antarctic aerosol samples) and trichomes of Leptolyngbya spp. (in Alpine snow samples). However, these specimens were not observed in growing stages. No eukaryotic microalgae specimens were observed. Only diatomempty frustules, or their segments, were recovered (e.g. genus of Gomphonema spp., Surirella spp., Fragilaria spp. and Nitzschia spp). However, as diatom frustules and their segments were at all times very rare, no effort was made to identify them by species. Diatoms were absent in the aerosol samples, indicating that their occurrence in the snow and ice was due to long-term deposition over time. Furthermore, due to pre-concentration (lyophilisation and centrifugation) of ice samples, diatom frustules were more common.

15 An unusual, large-celled, culturable pigmented prokaryote (Figs. 1a, b, c, d, e, f) was found in both alpine snow and aerosol samples. It was most abundant in snow and absent in the ice. In original samples the brownish cell aggregates (Figs. 1a, b, c) of many $\mu \mathrm{m}$ in size (10 to $50 \mu \mathrm{m}$ ) were frequently found, however, during cultivation in liquid media from those mats, single cells were disengaged (Fig. 1d). We at first 20 thought this bacterium was a small coccoid cyanobacterium (Chroococcales), due to its pigmentation (brownish) and size. Transmission electron microscopy also showed that the cells are wrapped into several mucilage layers (Fig. 1e) as it is common in several cyanobacteria species. Furthermore, the organism grew better in the light than in the dark. However, epifluorescence microscopy (Fig. 1f) showed that it is a prokaryotic microorganism without chlorophyll fluorescence. The absence of photosynthetic pigments was confirmed with liquid chromatography. At present we do not know the identity of this unusual organism, but hope to conduct further studies to determine its taxonomic placement.

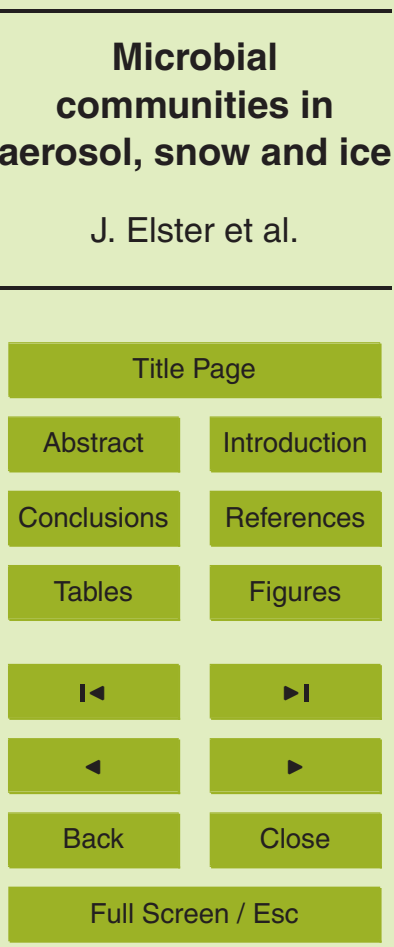

Printer-friendly Version

Interactive Discussion 
Microbial community and biotic remnants were evaluated by repeated releves of three treatments (aerosol, snow and ice) - characterized by their presence or absence. All methods produced distinct taxa lists that were used in the multivariate analyses. Nine 5 different categories of microorganisms and remnants of biological material were used as individual parameters in PCA: coccoid (CO), rod $(\mathrm{R})$, and red clusters of bacteria $(R C)$; unusual prokaryote (UP); hyphae $(\mathrm{H})$, and spores of fungi $(\mathrm{S})$; yeast $(\mathrm{Y})$; diatom valves (DV); and pollen (P). Red clusters of bacteria are flocks of filamentous bacteria of red color mixed with dust particles.

A single PCA was performed. The first component axis explained $31 \%$ of the variability of the data, with the second axis explaining an additional $14.8 \%$. In addition, the Monte Carlo permutation tests performed in studied treatments (aerosol, snow and ice) showed highly significant differences in both microbial community and biotic remnant composition ( $F=9.33, p=0.001)$. GLM tests also showed that there are significant differences between the numbers of categories of microorganisms and remnants of biological material in studied samples: a) aerosol $x$ snow $x$ ice $(F=11.45, p=0.00005)$; b) snow $x$ aerosol $(F=10.80, p=0.00259)$; and $c)$ snow $x$ ice $(F=22.71, p=0.00001)$. However, there aren't any significant differences between aerosol $x$ ice $(F=0.97, p=0.32841)$. Three separate plots were prepared to accentuate the differences between sample type. The Antarctic aerosol samples were characterised by having red clusters of bacteria, unusual prokaryote, and yeasts - with lesser occurrences of coccoid bacteria, fungal spores, and pollen (Fig. 2a). However, the high mountain snow from the Alps and Andes contained many more viable heterotrophs. (Fig. 2b). The unusual prokaryote was very abundant, as were coccoid bacteria, red clusters of bacteria, and yeasts. 25 The placement of the samples in the lower right quadrant of the ordination is most likely due to the near absence of fungal hyphae from these samples. Graphs 2A and 2B are more or less similar. Coccoid bacteria, red clusters of bacteria, the unusual prokaryote, spores of fungi, yeast, and pollen were all represented more frequently. These microor-
BGD

4, 1779-1813, 2007
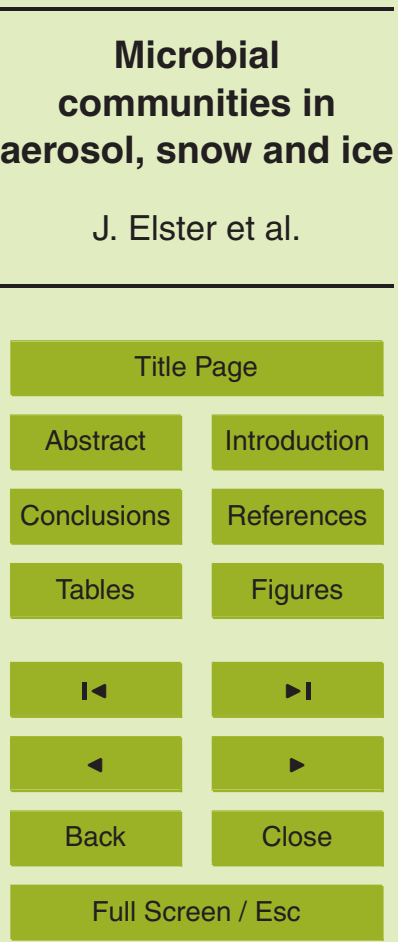

Printer-friendly Version

Interactive Discussion 
ganisms are generally typical of crustal aerosols. In addition, the comparison of these two diagrams indicates that more categories of microorganisms and remnants of biological material (average number) are present in high altitude snow (4.29) (in the Alps, as in the Andes) - than in the Antarctic aerosol (2.36). The Antarctic ice samples were 5 quite different from the aerosols and snows (Fig. 2c). These samples had higher numbers of rod bacteria and fungal hyphae. The highest average number of categories of microorganisms and remnants of biological material in the Antarctic aerosol was 2.76.

\subsection{Community composition - the detail view}

Between biotic remnants, mentioned above, the most surprising from the Antarctic aerosol samples were the tripolar pollen grains Betula type (Figs. 3a, b), and grains resembling types of Pinus or Cedrus (Fig. 3c). Although fungi were nearly absent from liquid cultures from alpine snow, they were fairly common in the solidified agar. These fungi were isolated from the solid algal media, and regrown on fungal enrichment media. The species diversity of fungi in the snow was much broader than in aerosol or ice samples. Some of the hyphae or spores belong to common species occurring in temperate anthropogenic environments. These species are typical of soils rich in organic matter, and often appear in laboratory contamination. However, the coprophilous soil genus Sporormiella, and/or Aureobasidium pollulans (Fig. 4a) (black yeast), which are natural in desert soils, may be imported from distant sources such as the Sahara. The genera Alternaria (Alernaria alternata - Figs. 4b, c), Botrytis spp., Cladosporium (Clodosporium herbarum - Fig. 4d), Ulocladium spp. and various fungi spores (Figs. 4e, f), observed in our Alps and Andean snow samples, are also ubiquitous in soils and continental aerosols. Plant pollens also occurred very commonly in snow samples. These plant pollens types: (Pinus - Fig. 5a, Abies - Fig. 5b, Betula - Figs. 5c, d, Almus viridis 25 - Fig. 5e and Dicranoweisia grimmiaceae - Fig. 5f) were recorded in the high mountain snow from the Alps sampling sites; as well as in the Andes (tripolar pollen grain Figs. 5g, h and Picea - Fig. 5i), respectively. In addition, the Monte Carlo permutation tests performed for Alps (Mt. Blank area) and Andean (Illimani, Bolivia) snow treat-

\section{BGD}

4, 1779-1813, 2007

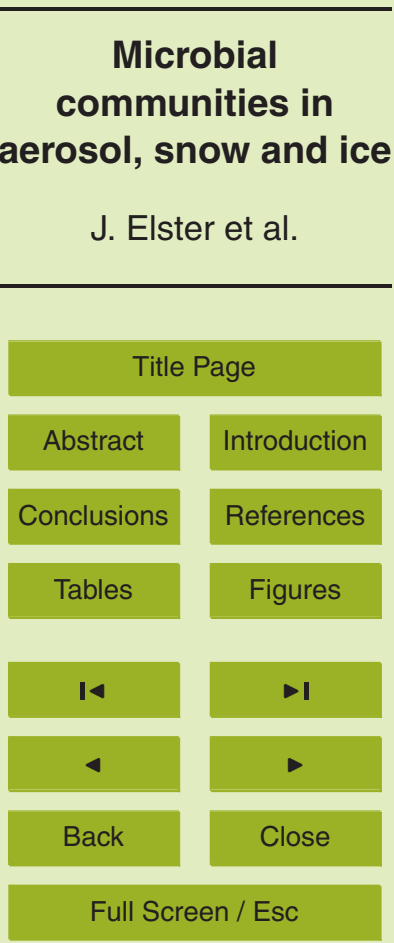

Printer-friendly Version

Interactive Discussion 
ments showed significant differences in both microbial community and biotic remnants composition ( $\mathrm{F}=2.20, \mathrm{p}=0.033$ ).

We did not find significant differences (the Monte Carlo permutation tests $-F=1.93$, $p=0.087$ ) in microbial community and biotic remnant composition between the two

5 Antarctic ice cores (D10 and Caroline). Also, differences between each of the core's parts were negligible. The upper $20 \mathrm{~m}$ of the cores are similar to firn in structure, the local origin ice. Cores depths from 145 to $170 \mathrm{~m}$ originated 80 to $100 \mathrm{~km}$ inland and cores depths below 210 of 145 to $170 \mathrm{~m}$ from ice originating from more than $200 \mathrm{~km}$ inland - is about 18000 year old. Frequently, there was a wide spectrum of fungi hy10 phae and spore specimens, some of them resembling Alternaria alternata (Figs. 4b, c), however, we are not certain concerning their taxonomical order because we did not cultivate them. In addition, fungal spores of various shapes and sizes (Figs. 6a, b), and one specimen resembling Pinus type pollen grain (Fig. 5a) were also recorded. Furthermore, in all three types of studied materials there were specimens, which we were not able to identify. The Monte Carlo permutation test was also performed for real (73 samples) and blank (4 samples) treatments $(F=1.31, p=0.229)$. This test demonstrates the problem of contamination.

\subsection{Evaluation of cultivation/pre-concentration efficiency}

Table 1 shows data evaluation of the liquid media cultivation methodology. In the table 20 only results of 26 Antarctic ice (D10 and Caroline) +2 blanks and 8 aerosol samples including blanks, analysed in 1999, are shown. The commonly used media for microautotrophs, BG 11 and BBM, showed the highest diversity of observed microorganisms. The rod bacteria and fungal hyphae predominated. Furthermore, in year 2000 cultivation experiments only BG11, BBM and Z, respectively were used (16 Antarctic 25 ice, 5 aerosol and 17 alpine snow samples +2 blanks). Again, the BG11 and BBM media introduced the highest microbial diversity. These differences were confirmed by the Monte Carlo permutation test $(F=3.07, p=0.001)$.

Forty-two Antarctic ice samples were pre-concentrated either by filtration (26 sam-

\section{BGD}

4, 1779-1813, 2007

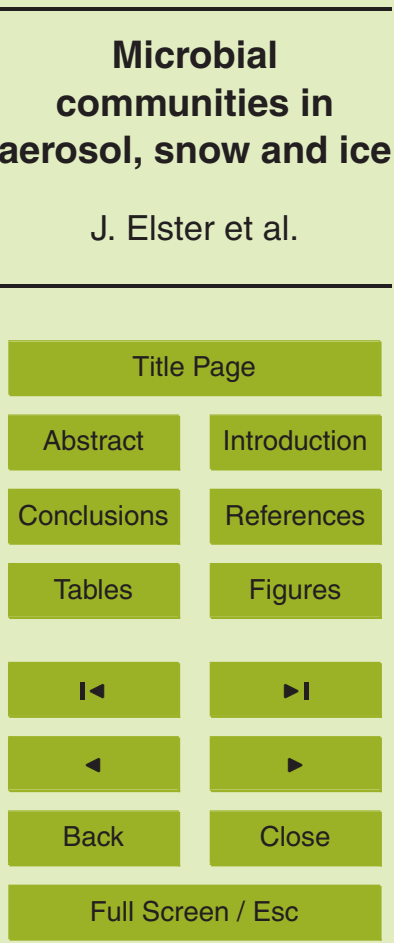

Printer-friendly Version

Interactive Discussion 
ples), centrifugation (5 samples), or lyophilisation (11 samples). The results, comparing the three methods of ice sample pre-concentration, show that they worked well (this includes both microbial communities and biotic remnants). In addition, the Monte Carlo permutation tests, comparing these three methods introduced high significant 5 differences $(F=16.85, p=0.001)$.

Sixteen (16) Antarctic ice, 4 Antarctic aerosol, 19 alpine snow samples and blanks were cultivated in liquid, as well as in solid media (BG11, BBM). The comparison of these two methodologies showed that liquid media offered better conditions for growth for most of the organisms present in the samples. In liquid media coccoid bacteria were 10 recorded 43 times, rod bacteria 20 times, bacterial red clusters 25 times, the unusual prokaryote 38 times, fungi hyphae 2 times, fungi spores 13 times, and yeasts 22 times. In solid media findings were less frequent (coccoid bacteria 10 times, rod bacteria 0 time, bacterial red clusters 0 time, the unusual prokaryote 0 time, fungi spores 4 times, and yeast 6 times). In solid media fungi hyphae were the exception at 7 times. 15 The significant differences are again confirmed by the Monte Carlo permutation tests $(F=13.00, p=0.001)$.

\subsection{Interaction of dust and organisms/remnants presence}

Table 2 shows the presence (percentage of presence in year 2000's cultivation experiments - 16 Antarctic ice, 5 aerosol, and 17 alpine snow samples) of organisms and 20 their remnants in samples, with and without dust. As has already been mentioned the data on dust presence/absence are based only upon observers' personal estimations. However, it is evident from Table 2, that in most of the samples studied, the presence of dust positively influenced the occurrence of organisms/remnants. However, coccoid bacteria, bacterial red clusters, yeasts, diatom valves, and plant pollen showed similar

\section{BGD}

4, 1779-1813, 2007

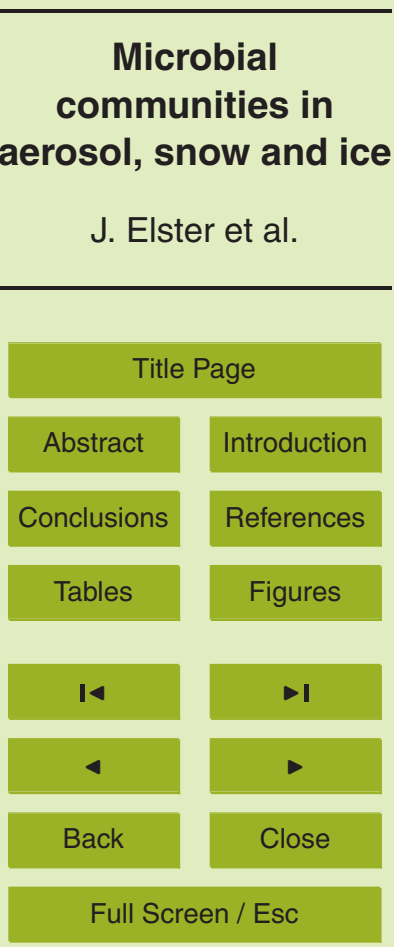

Printer-friendly Version

Interactive Discussion 


\subsection{Results survey}

Table 3 compares the presence (percentage of presence in all studied samples) of organisms and their remnants in the coastal Antarctic aerosol, Alps/Andean snow, and Antarctic ice. The aerosol samples were the poorest in microbial presence and quency. The snow samples were the richest in the presence of organisms. In all studied snow samples coccoid bacteria were present. The unusual prokaryote, red bacterial clusters, together with yeast, were commonly recorded in most studied snow samples. The Antarctic ice has been mainly rich in fungi hyphae and rod bacteria. The unusual prokaryotes were not recorded in analyzed ice. Biotic remnants (plant pollens, diatom valves, and fungi spores) were most frequently recorded in snow samples. However, fungi spores (culturable or just remnants) occurred in high percentages in all studied samples.

\section{Discussion}

15 Cyanobacteria and eukaryotic microalgae have been routinely recorded in dust and aerosols (airborne algae) in a wide range of latitudes (Broady, 1979; Tiberg et al., 1983; Marshal and Chalmers, 1997; etc.). In Polar Regions, long distance transport of airborne algae has been mainly studied in the Antarctic (e.g. Rudolph, 1970; Broady, 1979; Broady and Smith, 1994; Marschall, 1996a, b; Broady, 1996; Marshal and Chalmers, 1997; etc.) because of the special interest in possible routes of genome transport from surrounding continents. These studies brought a wide spectrum of ecological information (e.g. strong associations between the numbers of airborne algae and dry conditions; most species collected from the air have been identified as soil algae; airborne algae growth often occurred around particles of soil or vegetation suggesting that algae are transported on these particles; number of algal propagules is related to the niche space available or the degree of site maturity, etc.). We familiar-

BGD

4, 1779-1813, 2007

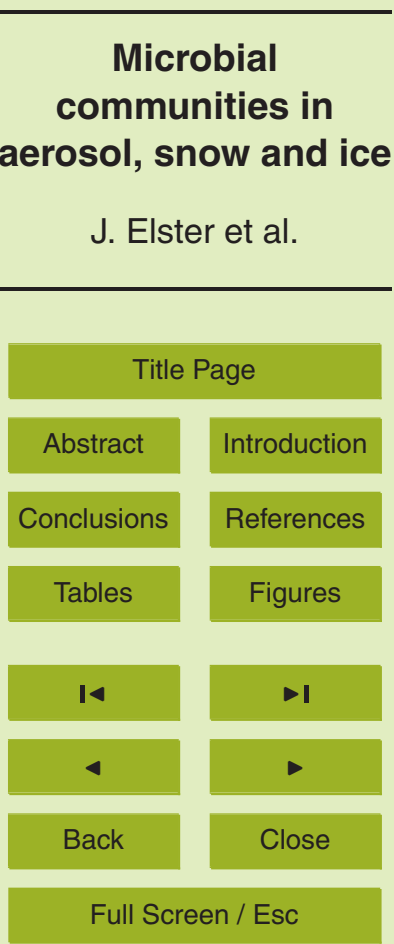

Printer-friendly Version

Interactive Discussion 
ized ourselves with all of this information before we (Czech phycologists and French glaciologists) proposed the experimental design of our study. The absence of culturable cyanobacteria and algae in all of our cultivation attempts (300 in all, from 77 samples) was surprising. Four media (three freshwater, one marine) in both liquid and solid 5 form were used, so the method of cultivation is likely not the problem. Furthermore, the filter quarters from the Antarctic ice (the Antarctic ice samples analysed in 1999) were clarified and examined with direct microscopy to see if the algae were present, but just not cultivatable. No cyanobacteria nor algal cells were observed in this way either. The evidence from the study suggests that none of the cyanobacteria and algae 10 species observable in samples, originating from particular remote and extremely cold landscapes, can be cultured. The ability to isolate and cultivate of both cyanobacteria and algae is currently the biggest block to the advancement of our knowledge concerning dispersal of their genome (Elster, 1999). This fact strongly limits our understanding of cyanobacteria and algae transport within remote localities and also in terms of long 15 distance intercontinental transport. In addition, inside of particularly remote and extremely cold landscapes there exists a complex, unpredictable environmental mosaic. There, airborne cyanobacteria and algae inoculum either can (or cannot) be collected and transported for short (or for long) distances. The availability (or unavailability) of cyanobacteria and algae inoculum in particular locations is probably one of the most 20 important.

The unusual large-celled and pigmented prokaryote was isolated from several aerosol and Alps/Andean snow samples. This species has also been observed in soils in King George Island, South Shetland Island group, Maritime Antarctica (J. Komárek, personal communication), as well in the Arctic Svalbard Islands (Řeháková, personal 25 communication). It looks as though this species commonly occurs in cold desert ecosystems and is easily transported with aerosols for both short and long distances. Imshsnetsky et al. (1978) suggested that the prevalence of pigmentation in viable bacteria, recovered from the mesosphere was associated with the need to absorb harmful UV-radiation. Moreover, it is clear that this species cannot be contamination. It has

\section{BGD}

4, 1779-1813, 2007

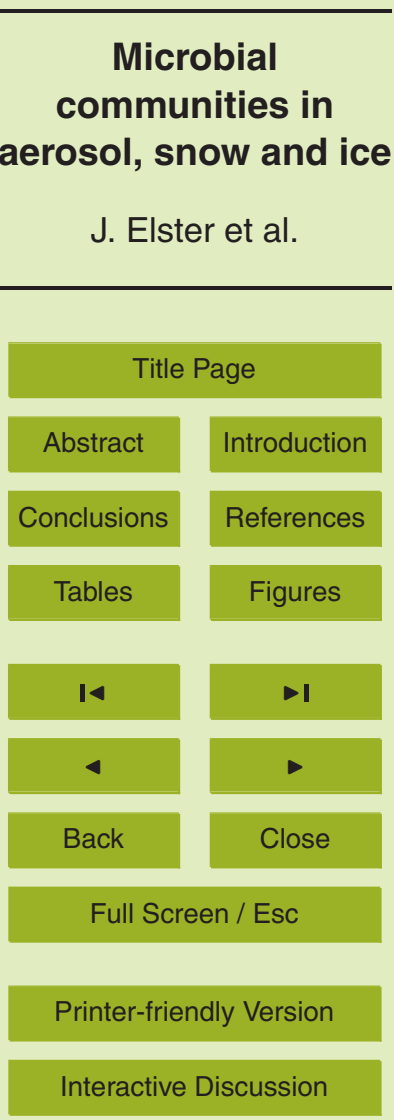

EGU 
never been found as a contamination agent in our phycology laboratory. Detailed analyses of this specimen (including DNA analyses) could help us understand the dispersal of its genome.

The station for collection of the Antarctic aerosol samples is situated on a small is5 land, a few hundred meters offshore of the mainland, close to the penguin rookeries and other habitats, and thus manured by various animal excrements. It is highly probable that heterotrophic microflora which occurred in our aerosol samples originated from these sources. There is evidence (Wynn-Williams, 1991) that there is a decrease in the density of aerial heterotrophic microflora with increasing distance from the coast.

10 The trend may be due, in part, to a denser source of propagules in the more-developed coastal communities including manured sites, or to the more favorable conditions for survival in less xeric coastal regions. However, the tripolar pollen grains (Betula type and grain resembling Pinus type or Cedrus type) found on aerosol filters most likely originated from contamination, which could have occurred during the field collection or during experimental procedures.

The high mountain snows from the Alps and Andes were the richest in the presence of organisms and biotic remnants. This observation agrees with the relatively large amounts of dust transported in the free troposphere of these regions. Saharan dust layers are very common in high altitude alpine snow (De Angelis and Gaudichet, 1991). The blocks of Alps' snow used in this study even recorded a Sahara dust event. Dust concentration was also relatively high in the snow deposited on the summit of Illimani (Clapperton, 1993), despite the absence of bare rocks near the sampling site. A high occurrence of culturable heterotrophs (unusual prokaryote, coccoid bacteria, red clusters of bacteria, and yeasts) in mountain snow is connected with the above mentioned dust transportation; and composition of recorded communities is typical for crustal aerosols. Similar results of high microbial abundances in snow were also demonstrated from various Antarctic localities (Wynn-Williams, 1991). However, in these geographically isolated localities this dust and microorganisms are of mainly local provenience and, to a lesser extent, the result of transport over the seas.

\section{BGD}

4, 1779-1813, 2007

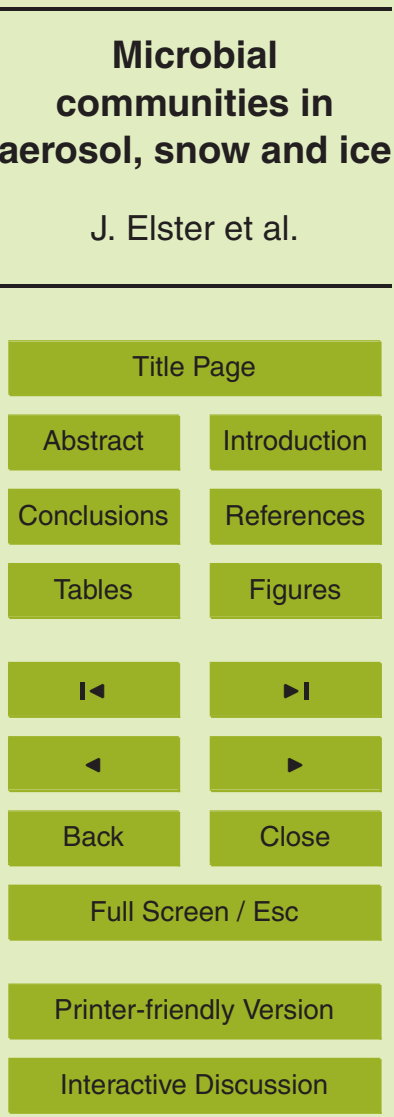

EGU 
The oversea transport appears to be sparse and is associated with weather patterns (Rudolph, 1970; Marschal, 1996b). High microbial diversity found in the snow from the Alps, has been followed by a broad spectrum of fungal spores and plant pollen. Most of the fungal spores belong to the most common species occurring in temperate 5 anthropogenic environments and/or are typical of soils rich in organic matter, and they also often appear in laboratory contamination. Marshal and Chalmers 1997 showed, that Sporormiella spp. and Cladosporium spp. fungal spores, found in our snow samples, belong the most abundant aerobiotas in most parts of the world, including maritime Antarctica. The high occurrence of temperate forest pollen grains confirms later 10 findings (Marshal and Chalmers, 1997) that the concentration of airborne spores in geographically isolated localities (e.g. Antarctica) is much smaller that at temperate sites. From our observations, it is evident that there exists in the Alps and Andes snows a mixture composed of microorganisms and biotic remnants assemblages which are of local origin, including contaminates that were brought from distant localities during 15 unusual weather conditions (storms, hurricanes, etc).

The Antarctic ice samples were quite different from the aerosols and snows. Rod bacteria and fungal hyphae were the most common here. These microorganisms are either contamination (mainly specimens resembling Pinus type pollen and a relatively wide spectrum of fungi spores) or their occurrence is associated with the presence of inorganic dust. It should be restated, that these results are linked to inland Antarctic snow samples, which receive long-range dust, transported mainly from southern South America (Raynaud et al., 1979). The idea that rod bacteria and fungi hyphae are associated with inorganic dust is supported by the fact that diatom valves, and, in part, also plant pollen and fungi spores are particles of long distance transport. In addition, the age of the ice, and the environmental conditions during glacial ice formation, are critical in terms of community composition. Abyzov (1993), showed that the microbial community of Lake Vostok ice in the upper portion of the core (last $3000 \mathrm{yrs}$ ) also includes culturable yeasts, fungal mycelia, and bacteria - dominated by non-sporulating forms such as Pseudomonas spp. Further down in the core, at an age of about 10000

\section{BGD}

4, 1779-1813, 2007

\section{Microbial \\ communities in \\ aerosol, snow and ice \\ J. Elster et al.}

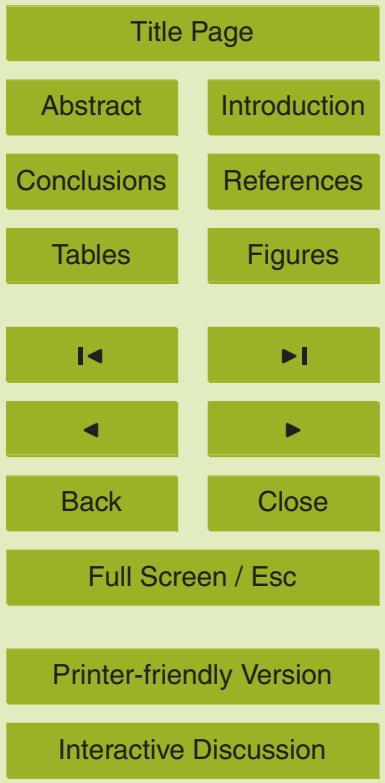

EGU 
years, microbial assemblage shifts to the dominance of spore-forming bacteria - and yeast are no longer detectable. We did not find significant differences in the microbial community between two Antarctic ice cores (D10 and Caroline) nor between their parts of the cores (different ages). No yeasts were detected in any of the ice types. In addi5 tion, we suspect that some of the difference in communities may be due to laboratory contamination of the re-distilled water used by the collection team from LGGE. This redistilled water is very clean with respect to mineral contaminants, but we subsequently learned that the redistilled water from LGGE had some microbial contaminants.

As has already been mentioned, it is evident that the experimental procedure used 10 in this study is not contamination-free, but our results demonstrate that the contamination is not overwhelming. The contamination linked to the analytical procedures could be expected to include commonly occurring bacteria, as well as small and light fungi, (e.g. hyphae and/or spores, plants pollen and remnants of diatoms). All of these contaminants are common in our laboratory, which works on photosynthetic cyanobacteria and algae. Some fungi can easily survive (even prosper) in conditions under UV-B radiation. UV-B radiation is commonly used for the sterilization of our phycology lab. This group can be classified as the community of ubiquitous organisms, including contaminants. The contamination issue has been confirmed by the analyses of blank samples. In all sets of analyses the blank vials (vials without a sample - just opened in the field; vials with distilled or re-distilled water used in sampling procedures) contained the ubiquitous organisms and the ubiquitous biotic remnants. The second community (unusual prokaryote; yeast, selected bacteria, and fungal spore's hyphae, as well as remnants of diatoms), represents individuals frequently occurring in remote terrestrial cold or hot deserts/semi-deserts, and/or marginal soil-snow-ice ecosystems. This group can be of local provenance or transported along with dust and can survive airborne for long periods. Detailed knowledge of the ecology and taxonomy of microorganisms originating from remote locations can help us to recognize these two groups. For example, in some cases we can even deduce from observation the type of habitats from which the organisms originate.

\section{BGD}

4, 1779-1813, 2007

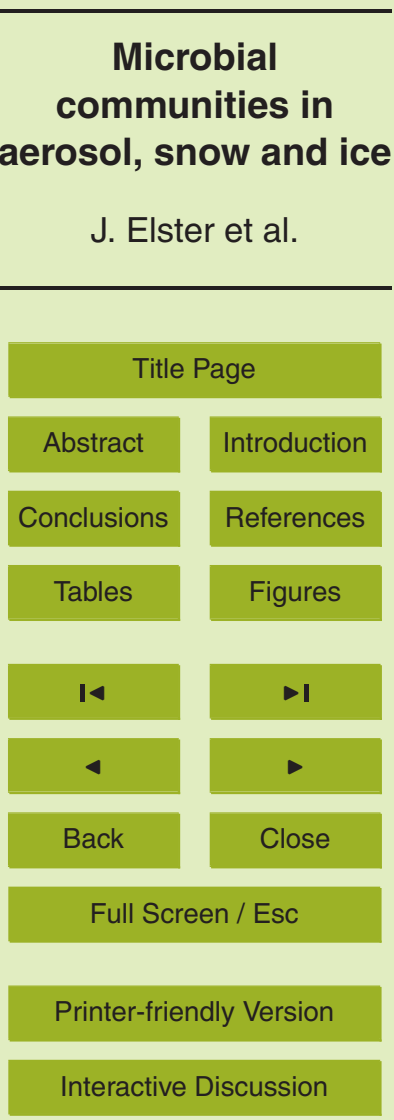

EGU 


\section{Summary}

The absence of micro-autotrophs in all cultivation attempts is surprising because cyanobacteria and algae have been routinely recorded in dusts and aerosols within a wide range of latitudes. The evidence from this study suggests that micro-autotrophs 5 are frequently not transported for long distances with air masses and/or they do not survive this transport. In addition, inside the studied remote and extremely cold landscapes there are habitats of chance "luck" with the occurrence of micro-autotrophs. An unusual, large-celled, culturable pigmented prokaryote was found in both alpine snow and aerosol samples. It looks as if this species commonly occurs in cold desert ecosys10 tems and is easily transported with aerosols, for both short and long distances. DNA analyses of this specimen could help us to understand the dispersal of its genome, and those genome segments found in glacial ice cores could be used as a biomarker for the identification of ecosystem type and climate changes.

Analyses of many samples and proper statistical analyses (PCA , RDA with Monte 15 Carlo permutation test) show that studied treatments of aerosol, snow and ice differ significantly in both microbial community and abiotic remnants composition $F=9.33$, $p=0.001$. In addition, the GLM tests showed that there are significant differences in the numbers of categories of microorganisms and remnants of biological material between studied samples of aerosol $x$ snow $x$ ice $-F=11.45, p=0.00005$; snow $x$ aerosol $20-F=10.80, p=0.00259$; and snow $x$ ice $-F=22.71, p=0.00001$, respectively. However, on the contrary, the Monte Carlo permutation tests showed there aren't any significant differences $(F=1.93, p=0.087)$ between the two Antarctic ice cores (D10 and Caroline). In addition, the GLM tests also showed that there aren't any significant differences in the numbers of categories of microorganisms and remnants of biological material between aerosol $x$ ice $(F=0.97, p=0.32841)$. The aerosol samples were poor in microbial presence (the highest average number of categories of microorganisms and remnants of biological material was 2.76), and only coccoid bacteria and the unusual prokaryote have been represented at higher frequencies. In all of the high mountain snow

BGD

4, 1779-1813, 2007

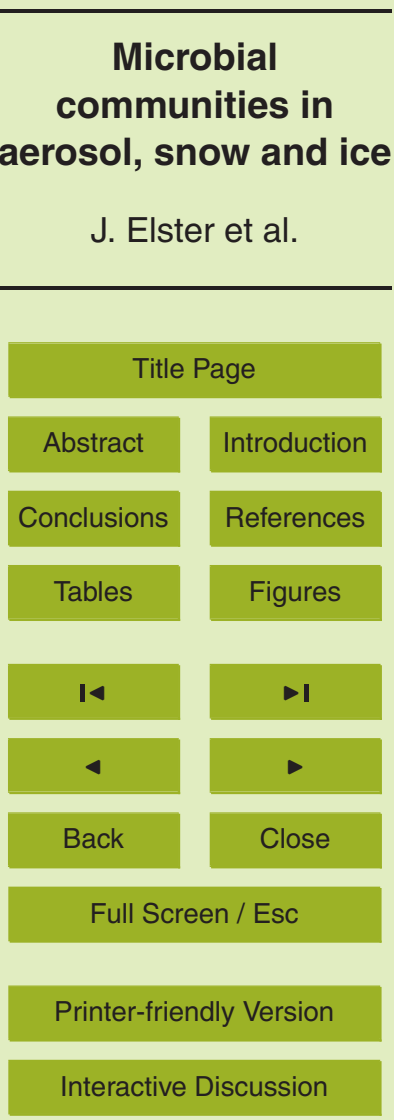

EGU 
samples studied (the highest average number of categories of microorganisms and remnants of biological material was 4.29), coccoid bacteria were present. Here, the unusual prokaryote was very abundant, as were red bacterial clusters, together with yeast. Biotic remnants (plant pollens, diatom valves, and fungi spores) were also most 5 frequently recorded in snow samples. Microorganisms and biotic remnants found in aerosol and snow samples are generally called crustal aerosols. The Antarctic ice samples were quite different from the aerosols and snows. These samples had higher numbers of rod bacteria and fungal hyphae (the highest average number of categories of microorganisms and remnants of biological material was 2.36). However, the Monte 10 Carlo permutation tests (no significant differences between real and blank samples $\mathrm{F}=1.31, \mathrm{p}=0.229$ ) demonstrate the contamination problems. Blanks for all three treatments were empty vials or plastic bags of the same type used for the collection of samples, washed out with the re-distilled water used in the sample preparation procedure. However, because only 4 blank and 73 sample treatments were statistically evaluated, 15 we believe that contamination problems are not overwhelming. Proper statistical analyses of many samples showed differences between studied treatments. The contamination is a serious problem that must be taken in consideration in future studies. The microbial communities and biological remnants of analysed samples comprises two communities, without a sharp boundary between them: i) the first community includes ubiquitous organisms including contaminants; ii) the second community represents individuals frequently occurring in remote terrestrial cold or hot desert/semi-desert and/or marginal soil-snow-ice ecosystems.

In addition to above-mentioned results, three methods (filtration, centrifugation and lyophilisation) for ice and snow sample's pre-concentration were evaluated. The re25 sults showed that all three pre-concentration methods worked well, however, the Monte Carlo permutation tests comparing these three methods showed highly significant differences $(F=16.85, p=0.001)$. Afterwards, cultivation methods for terrestrial, freshwater and marine micro-autotrophs and micro-fungi together with liquid and solid media were tested. The commonly used media for micro-autotrophs, BG 11 and BBM,

\section{BGD}

4, 1779-1813, 2007

\section{Microbial \\ communities in \\ aerosol, snow and ice \\ J. Elster et al.}

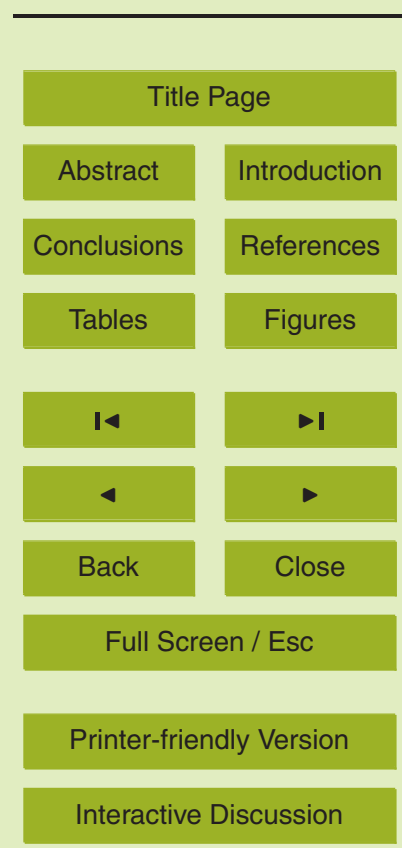

EGU 
showed the highest diversity of observed microorganisms. The differences between cultivation media ware again confirmed by the Monte Carlo permutation tests $(F=3.07$, $p=0.001$ ). The comparison of the liquid and solid media clearly show that the liquid media offer better conditions for growth for most microorganisms present in the sam5 ples. The significant differences between these two methods are again confirmed by the Monte Carlo test $(F=13.00, p=0.001)$.

The study showed that there is still some "luck" in information concerning transportation of micro-autotrophs, micro-fungi, bacteria and yeast (in culturable stage or in remnants stage) by air masses, and later their storage in snow and icecaps around 10 the world. Such research is highly important. The collection of material for analyses in remote localities is not easy. The future studies have to be focussed for development of sampling methodology, which will eliminate contamination. The second most urgent task pointed out by this study is to employ in the future studies the classical microscopy and cultivation techniques in combination with molecular biology methods.

Acknowledgements. This work has been carried out in the framework of the French-Czech cooperative research program BARRANDE No. 99054. The work has also been supported by projects of: the Grant Agency of the Czech Republic (206/05/0253), and the Grant Agency of the Ministry of Education of the Czech Republic (MSMT 6007665801). We acknowledge the contribution of IRD (Institut de Recherche pour le Dévelopment) for the sampling and transportation of the Illimani snow samples. We are also very grateful to B. Jourdain (Laboratoire de Glaciologie et Géophysique de l'Environnement du CNRS, St Martin d'Hères, France) for collection of the Antarctic aerosol samples. Our appreciation is also given to M. Váňová, A. Kubátová, K. Prášil (Charles University, Faculty of Natural Sciences, Prague) for micro-fungi identification and V. Jankovská (Institute of Botany, Academy of Sciences of the Czech Republic, Brno) analyses and D. Śvehlová for technical assistance. J. R. Johansen (John Carroll University, University Heights, Ohio, USA) was so kind and gave us critical comments on the manuscript.

BGD

4, 1779-1813, 2007

\section{Microbial \\ communities in \\ aerosol, snow and ice \\ J. Elster et al.}

\section{Title Page}

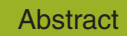

Introduction

Conclusions

References

Tables

Figures

14

4

Back

Close

Full Screen / Esc

Printer-friendly Version

Interactive Discussion 


\section{References}

Abyzov, S. S.: Microorganisms in the Antarctic ice. In Friedmann El (ed.), Antarctic Microbiology, Wiley-Liss, New York, 265-295, 1993.

Bischoff, H. W and Bold, H. C.: Some algae from Enchanted Rock and related algal species. Phycological studies. University of Texas, IV. Austin (University of Texas Publication 6318). 68 pp., 1963.

Bold, H. C.: The morphology of Chlamydomonas chlamydogama, sp. nov. Bull. Torrey Bot. Club, 76, 101-108, 1949.

Broady, P. A.: Wind dispersal of terrestrial algae at Signy Island, South Orkney Islands, Brit. Antarc. Survey Bull., 48, 99-102, 1979.

Broady, P. A.: Diversity, distribution and dispersal of Antarctic algae, Biodiv. Conserv., 5, 13071335, 1996.

Broady, P. A. and Smith, R. A.: A preliminary investigation of the diversity, survivability and dispersal of algae introduced into Antarctica by human activity, Proc. NIPR Simp. Polar Biol., 7, 185-197, 1994.

Chalmers, M. O., Harper, M. A. and Marshall, W. A.: An Illustrated Catalogue of Airborne Microbiota from the Maritime Antarctic. British Antarctic Survey, 175, 1996.

Clapperton, C. C.: Quaternary Geology and Geomorphology of South America. Elsevier Science Publ., Amsterdam, 780 pp., 1993.

20 De Angelis, M. and Gaudichet, A.: Saharan dust deposition over Mont Blanc (French Alps) during the last 30 years, Tellus, 43B, 61-75, 1991.

Delmas, R. J.: Environmental information from ice cores, Rev. Geophys., 30(1), 1-21, 1992.

Elster J.: Algal versatility in various extreme environments, in: Enigmatic Microorganisms and Life in Extreme Environments, edited by: Seckbach, J., Kluver Academic Publishers, 215227, 1999.

Elster, J. and Benson, E. E.: Life in the Polar Terrestrial Environment: A Focus on Algae, in: Life In The Frozen State, edited by: Fuller, B., Lane, N., and Benson, E. E., Taylor and Francis, London, 111-149, 2004.

Elster, J., Lukešová, A., Svoboda, J., Kopecký, J., and Kanda, H.: Diversity and abundance of soil algae in the polar desert, Sverdrup pass, central Ellesmere Island. Polar Rec., 35(194), 231-254, 1999.

Flechtner, V. R.: Enigmatic desert soil algae. Soil algal flora of the Western U.S.A. and baja
BGD

4, 1779-1813, 2007

Microbial

communities in

aerosol, snow and ice

J. Elster et al.

Title Page

Abstract

Introduction

Conclusions

References

Tables

Figures

14

$\rightarrow$

4

Back

Close

Full Screen / Esc

Printer-friendly Version

Interactive Discussion 
California, Mexico, in: Enigmatic Microorganisms and Life in Extreme Environments, edited by: Seckbach, J., Kluver Academic Publishers, 231-241, 1999.

Garty, J.: Lithobionts in the Eastern Mediterranean, in: Enigmatic Microorganisms and Life in Extreme Environments, edited by: Seckbach, J., Kluver Academic Publishers, 255-276, 1999.

Gilichinsky, D. A., Vorobyova, E. A., Erokhina, D. G., Fyordorov-Davydov, D. G., and Chaikovskaya, N. R.: Long-term preservation of microbial ecosystems in permafrost, Adv. Space Res., 12(4), 255-263, 1992.

König-Langlo, G., King, J., and Pettré, P.: Climatology of the three coastal Antarctic stations 10

Imshenetsky, A. A., Lysenko, S. V., and Kazakov, G. A.: Upper boundary to the biosphere, Appl. Environ. Microbiol., 35, 1-5, 1978.

ISO 12253: Water quality - marine algal growth inhibition test with Skeletonema costatum and Phaeodactylum tricornutum. International standard office, 8 pp., 1995.

15 Legrand, M., Ducroz, F., Wagenbach, D., Mulvaney, R., and Hall, J.: Ammonium in coastal Antarctic aerosol and snow: Role of the polar ocean and penguin emissions, J. Geophys. Res., 103(D9), 11043-11 056, 1998.

Lepš, J. and Šmilauer, P.: Multivariate analysis of ecological data using CANOCO. ISBN 0-52181409 X, Cambridge University Press, 1-269, 2003.

20 Marshall, W. A.: Aerial dispersal of lichen soredia in the maritime Antarctic, New Phytol., 134, 523-530, 1996a.

Marshall, W. A.: Biological particles over Antarctica, Nature, 383, 680, 1996b.

Marshall, W. A. and Chalmers, M. O.: Airborne dispersal of antarctic terrestrial algae and cyanobacteria, Ecography, 20, 585-594, 1997.

McCullagh, P. and Nelder, J. A.: Generalized linear models. (second edition) Chapman and Hall, London, UK, 1-174, 1989.

Minikin, A., Legrand, M., Hall, J., Wagenbach, D., Kleefeld, C., Wolff, E., Pasteur, E. C., and Ducroz, F.: Sulfur-containing species (sulfate and methanesulfonate) in coastal Antarctic aerosol and precipitation, J. Geophys. Res., 103(D9), 10 975-10 990, 1998.

30 Oeschger, H., Schotterer, U., Stauffer, B., Haeberli, W., and Röthlisberger, H.: First results from Alpine core drilling projects. Ztschr. Gletscherk, Glazialgeolog., 13(1/2), 193-208, 1977.

Pedersen, K.: Diversity and activity of microorganisms in deep igneous rock aquifers of the Fennoscandian shield, in: Subsurface Microbiology and Biochemistry, edited by: Fredrick-

\section{BGD}

4, 1779-1813, 2007

\section{Microbial \\ communities in \\ aerosol, snow and ice \\ J. Elster et al.}

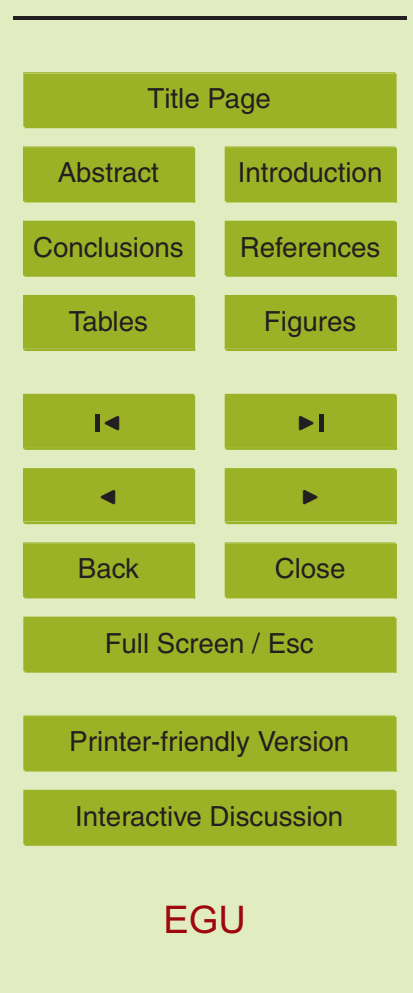


son, J. K. and Fletcher, M., ISBN 0-471-31577-X, Wiley-Liss, Inc., 97-139, 2001.

Périard, C. and Pettré, P.: Some aspects of the climatology of Dumont d'Urville, Adélie Land, Antarctica. Int. J. Climatol., 13, 313-327, 1992.

Priscu, J. C., Adams, E. E., Lyons, W. B., Voytek, M. A., Mogk, D. W., Brown, R. L., McKay, C. 5 P., Takacz, C. D., Welch, K. A., Wolf, F. C., Kirshtein, J. D. and Acci, R.: Geomicrobiology of subglacial ice above lake Vostok, Antarctica. Sci., 286, 2141-2144, 1999.

Raynaud, D., Lorius, C., Budd, W. F., and Young, N. W.: Ice flow along an I.G.B.P. flow line and interpretation of data from an ice core in Terre Adélie, Antarctica, J. Glaciol., 24(90), 103-115, 1979.

10 Risacher, F.: Géochimie des lacs salés et croûtes de sel de l'Altiplano Bolivien, Sci. Geol. Bull., 45, 135-214, 1992.

Rudolph, E. D.: Local dissemination of plant propagules in Antarctica, in: Antarctic ecology, edited by: Holdgate, M. W., Academic Press, 812-817, 1970.

Sattler, B., Puxbaum, H. and Psenner, R.: Bacterial growth in supercooled cloud droplets,

15 Geophys. Res. Lett. 28(2), 239-242, 2001.

Schopf, J. W.: Cradle of life. The Discovery of Earth's earliest fossils. Princeton University Press, Princeton, New Jersey, 336 pp., 1999.

Seckbach, J. (Ed): Enigmatic microorganisms and life in extreme environments. Kluver Academic Publishers, pp. 687, 1999.

20 Siegert, M. J., Ellis-Evans, J. C., Tranter, M., Mayer, C., Petit, J. R., Salamatin, A., and Priscu J. C.: Physical, chemical and biological processes in Lake Vostok and other Antarctic subglacial lakes, Nature, 414, 603-609, 2001.

Staub, R.: Untersuchungen an der Blaualge Oscillatoria rubescens DC. Schweiz, Z. Hydrol., 23, 83-198, 1961.

Ter Braak, C. J. F. and Šmilauer, P.: CANOCO Release 4. Reference manual and user's guide to Canoco for Windows: Software for Canonical Community Ordination. Microcomputer Power, Ithaca, New York, 352 pp., 1998.

Tiberg, E., Bergman, B., Wictorin, B., and Willén, T.: Occurrence of microalgae in indoor and outdoor environments in Sweden, in: Nordic earobiology, edited by: Nilsson, S. and Raj, B., Amqvist and Wiksell, Stockholm, 24-29, 1983.

Van Thielen, N. and Garbary, D. J.: Life in the rocks - endolithic algae, in: Enigmatic Microorganisms and Life in Extreme Environments, edited by: Seckbach, J., Kluver Academic Publishers, 243-253, 1999.

\section{BGD}

4, 1779-1813, 2007

Microbial

communities in

aerosol, snow and ice

J. Elster et al.

Title Page

Abstract

Introduction

Conclusions

Tables

References

Figures

14

$\rightarrow$

4

Back

Close

Full Screen / Esc

Printer-friendly Version

Interactive Discussion 
Wagenbach, D.: Environmental records in Alpine glaciers, in: The environmental records in glaciers and ice sheets, edited by: Oeschger, J. H. and Langway, C. C. John Wiley \& Sons Limited, 69-83, 1989.

Wagenbach, D., Ducroz. F., Mulvaney, R., Keck, L., Minikin, A., Legrand, M., Hall, J. S., 5 and Wolff, E. W.: Sea-salt aerosol in coastal Antarctic regions, J. Geophys. Res., 103(D9), 10961-10 974, 1998.

Wynn-Williams, D. D.: Aerobiology and colonization in Antarctica - The BIOTAS Programme, Grana, 30, 380-393, 1991.

Yao Tan Dong, Petit J. R., Jouzel, J., Lorius, C., and Duval, P.: Climatic record from an ice margin area in East Antarctica, Ann. Glaciol., 14, 323-327, 1990.

Zachleder, V. and Cepák, V.: Visualisation of DNA containing structures by fluorochrome DAPI in those algal cells that are not freely permeable to the dye, Arch. Hydrobiol./ Algolog. Stud., 47, 157-168, 1987.

\section{BGD}

4, 1779-1813, 2007

\section{Microbial}

communities in aerosol, snow and ice

J. Elster et al.

\section{Title Page}

Abstract

Introduction

Conclusions

References

Tables

Figures

14

\section{$>1$}

4

Back

\section{Full Screen / Esc}

Printer-friendly Version

Interactive Discussion 


\section{BGD}

4, 1779-1813, 2007

Microbial

communities in aerosol, snow and ice

J. Elster et al.

Table 1. Liquid media (BG11, BBM, Sea water, Z) evaluations of Antarctic ice and aerosol samples is introduced. Numbers in the table represent the occurrence of bacteria, micro-fungi, yeast and remnants of diatom valves/pollen in different treatments. Abbreviations of organisms in studied samples: cocci (CO), rod (R), red clusters of bacteria (RC); unusual prokaryote (UP); hyphae $(\mathrm{H})$, and spores of fungi $(\mathrm{S})$; yeast $(\mathrm{Y})$; diatom valves $(\mathrm{DV})$; and pollen of plants $(\mathrm{P})$.

\begin{tabular}{lllllllllll}
\hline Media type & CO & R & RC & UP & H & S & Y & DV & P & Sum \\
\hline Sum of BG11 & 3 & 13 & 8 & 1 & 24 & 3 & 0 & 0 & 0 & 52 \\
Sum of BBM & 3 & 18 & 0 & 1 & 20 & 3 & 0 & 0 & 0 & 45 \\
Sum of Sea water & 1 & 7 & 0 & 0 & 7 & 1 & 0 & 1 & 0 & 17 \\
Sum of Z & 4 & 7 & 0 & 1 & 9 & 3 & 0 & 0 & 0 & 24 \\
Total sum & 11 & 45 & 8 & 3 & 60 & 10 & 0 & 1 & 0 & 138 \\
\hline
\end{tabular}




\section{BGD}

4, 1779-1813, 2007

\section{Microbial}

communities in aerosol, snow and ice

J. Elster et al.

Table 2. Evaluation of the presence of inorganic dust on organisms occurrence is shown. Numbers in the table show the presence (\%) in analysed samples of: bacteria, micro-fungi, yeast and remnants of diatom valves/pollen in the studied samples. Abbreviations of organisms in studied samples: cocci (CO), rod (R), red clusters of bacteria (RC); unusual prokaryote (UP); hyphae $(H)$, and spores of fungi $(S)$; yeast $(Y)$; diatom valves $(D V)$; and pollen of plants $(P)$.

\begin{tabular}{llllllllll}
\hline Presence/absence of dust & $\mathrm{CO}$ & $\mathrm{R}$ & $\mathrm{RC}$ & $\mathrm{UP}$ & $\mathrm{H}$ & $\mathrm{S}$ & $\mathrm{Y}$ & $\mathrm{DV}$ & $\mathrm{P}$ \\
\hline Average with dust (\%) & 36 & 46 & 21 & 23 & 51 & 19 & 12 & 0 & 2 \\
Average without dust (\%) & 39 & 22 & 16 & 13 & 16 & 10 & 11 & 1 & 3 \\
\hline
\end{tabular}

Title Page

Abstract

Introduction

Conclusions

References

Tables

Figures

14

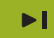

4

Back

\section{Full Screen / Esc}

Printer-friendly Version

Interactive Discussion 


\section{BGD}

4, 1779-1813, 2007

\section{Microbial}

communities in aerosol, snow and ice

J. Elster et al.

Table 3. Comparison of occurrences of organisms in aerosol, snow and Antarctic ice samples is introduced. Numbers in the table show the presence (\%) in analysed samples of bacteria, micro-fungi, yeast, diatom valves remnants and pollen in studied samples. Abbreviations of organisms in the studied samples: cocci $(\mathrm{CO})$, rod $(\mathrm{R})$, red clusters of bacteria $(\mathrm{RC})$; unusual prokaryote (UP); hyphae (H), and spores of fungi (S); yeast (Y); diatom valves (DV); and pollen of plants $(P)$.

\begin{tabular}{llllllllll}
\hline Origin of samples & $\mathrm{CO}$ & $\mathrm{R}$ & $\mathrm{RC}$ & $\mathrm{UP}$ & $\mathrm{H}$ & $\mathrm{S}$ & $\mathrm{Y}$ & $\mathrm{DV}$ & $\mathrm{P}$ \\
\hline Average of aerosol (\%) & 35 & 19 & 19 & 38 & 0 & 15 & 15 & 0 & 4 \\
Average of snow (\%) & 100 & 37 & 59 & 88 & 6 & 32 & 53 & 3 & 9 \\
Average of ice core (\%) & 30 & 54 & 25 & 0 & 56 & 15 & 0 & 1 & 2 \\
\hline
\end{tabular}



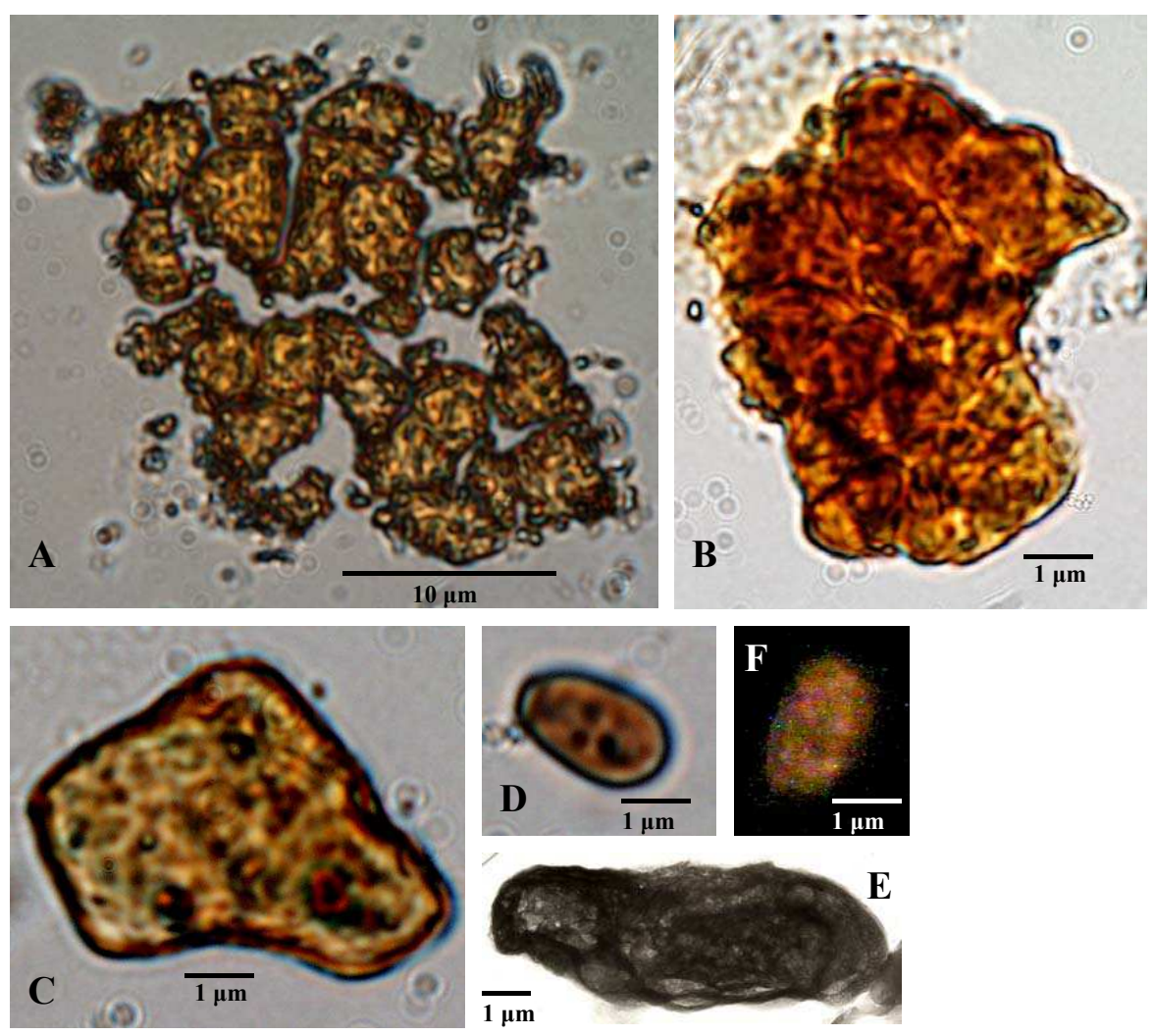

Fig. 1. Examples of photos of the unusual prokaryote found in the aerosol and snow samples. Photos from light, fluorescence and transmission electron microscopy are shown. Picture: (A) from the Dumont d'Urville Station (Antarctic aerosol) - light microscopy, (B) - from Illimani (Andean snow) - light microscopy, (C) - from the Mt. Blanc area (Alpine snow) - light microscopy, (D) - from the Mt. Blanc area (Alps snow) - light microscopy, (E) - from Illimani (Andean snow) - transmission electron microscopy, (F) - from the Dumont d'Urville Station (Antarctic aerosol) - fluorescence microscopy.

\section{BGD}

4, 1779-1813, 2007

\section{Microbial communities in} aerosol, snow and ice

J. Elster et al.

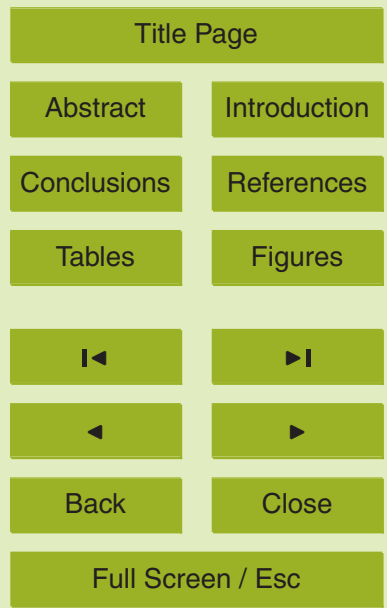

Printer-friendly Version

Interactive Discussion 
BGD

4, 1779-1813, 2007
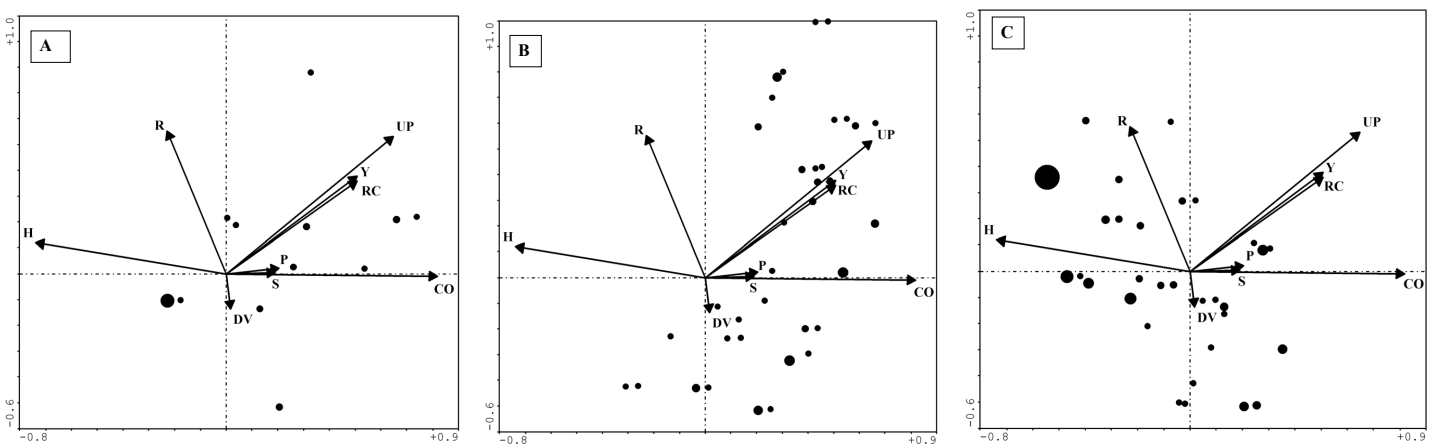

Fig. 2. Results of PCA ordination analyses for bacteria (rod, cocci, red clusters and unusual prokaryote); micro-fungi (hyphae and spores); yeast, remnants of diatom valves and pollen presence/absence - extracted from various samples: (A) - Antarctic aerosol filters (Dumont d'Urville, Terre Adélie); (B) - Alps (Mt Blanc area) and Andean snow (Illimani, Bolivia), (C) Antarctic ice (Terre Adélie) is shown. Abbreviations for microorganisms in studied samples: rod $(R)$, cocci $(C O)$, red clusters of bacteria $(R C)$, unusual prokaryote (UP), hyphae $(H)$, spores of fungi $(S)$, yeast $(Y)$, valves of diatoms $(V D)$, and plant pollen grains $(P)$. Figures show the relationship of organisms in the aerosol, snow and glacial ice environments. Note that the arrow's direction reflects the increasing probability of occurrence. Larger size circles show higher numbers of samples taken at the same point.
Microbial

communities in aerosol, snow and ice

J. Elster et al.

\section{Title Page}

Abstract

Introduction

Conclusions

References

Tables

Figures

14

$\rightarrow$

4

Back

Close

\section{Full Screen / Esc}

Printer-friendly Version

Interactive Discussion 

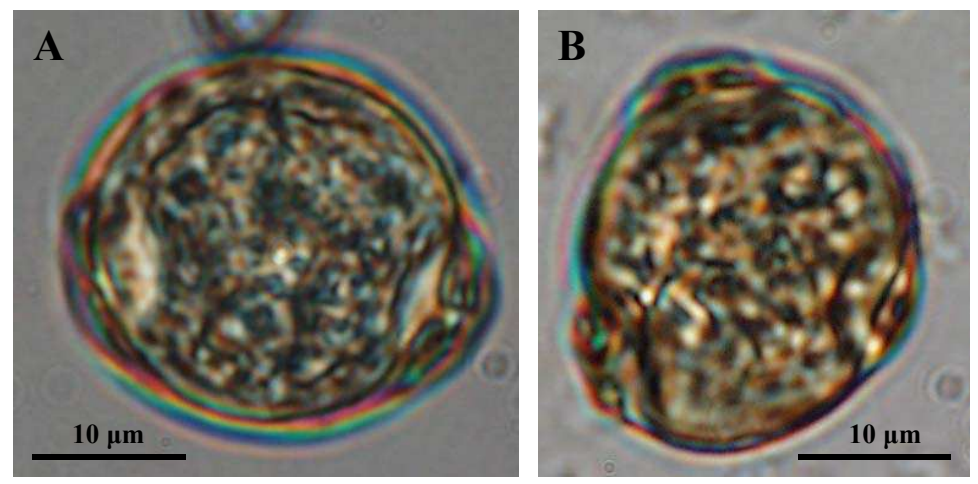

\section{BGD}

4, 1779-1813, 2007

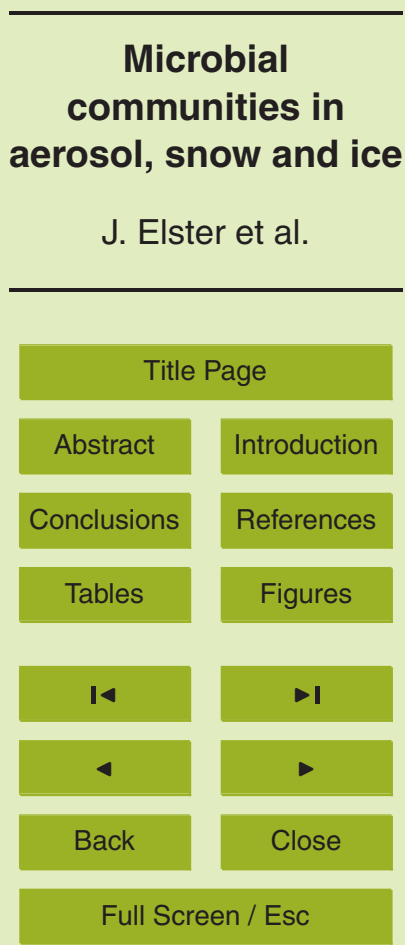

Printer-friendly Version

Fig. 3. Examples of photos of plant pollen grains from the Dumont d'Urville Station (Antarctic aerosol). Pictures (A) and (B) - triporate pollen grains Betula, (C) - grain resembling type Pinus or Cedrus.

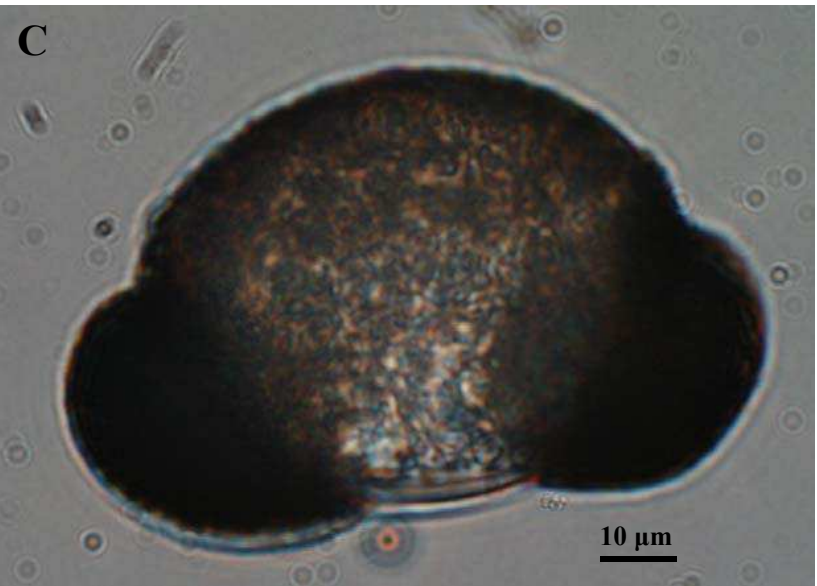

Interactive Discussion 


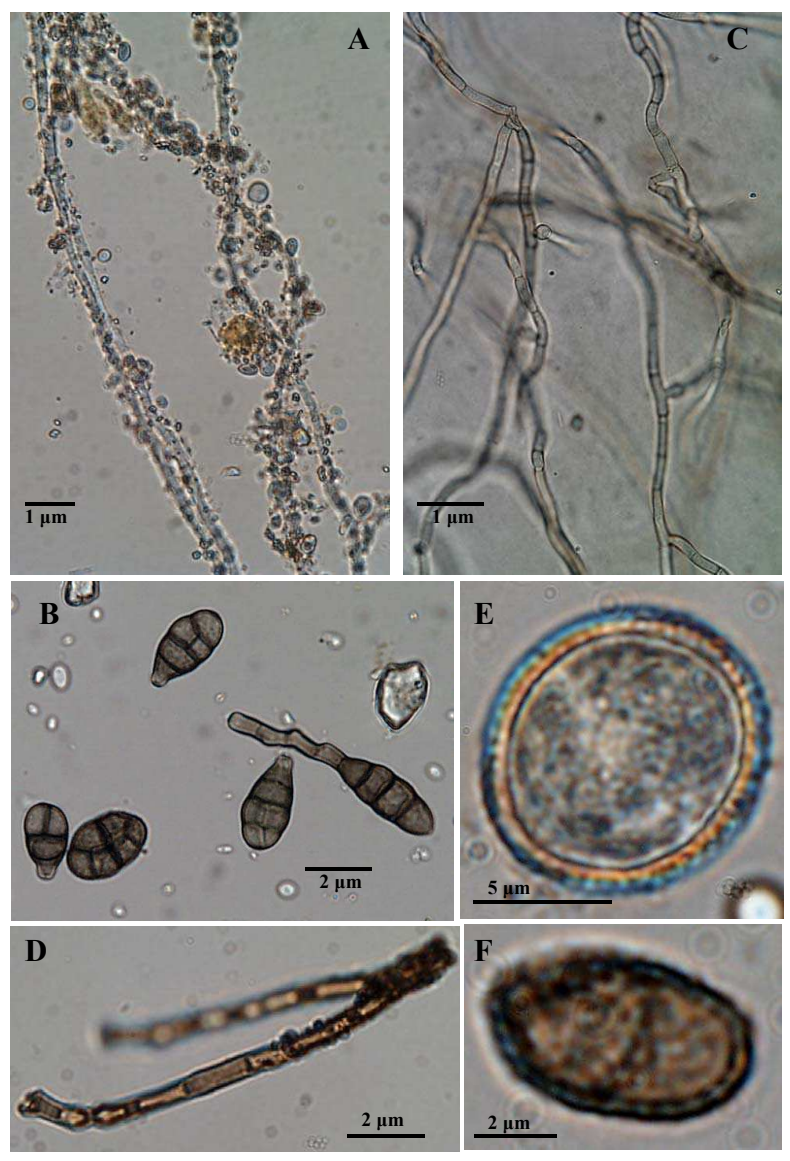

Fig. 4. Examples of photos of fungi hyphae and spores from Alps snow (Mt. Blanc area). Picture (A) - hyphae of Aureobasidium pollulans, (B) - hyphae and (C) - spores of Alternaria alternata, (D) - hyphae of Clodosporium herbarum, (E), (F) - various fungi spores.

\section{BGD}

4, 1779-1813, 2007

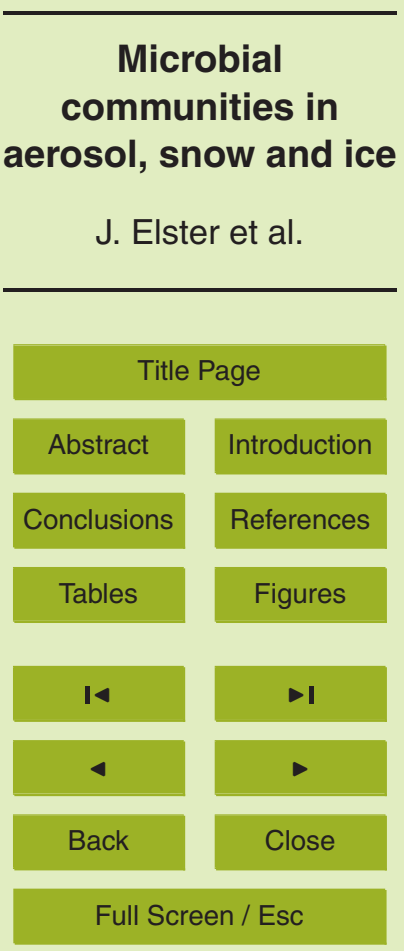

Printer-friendly Version

Interactive Discussion 

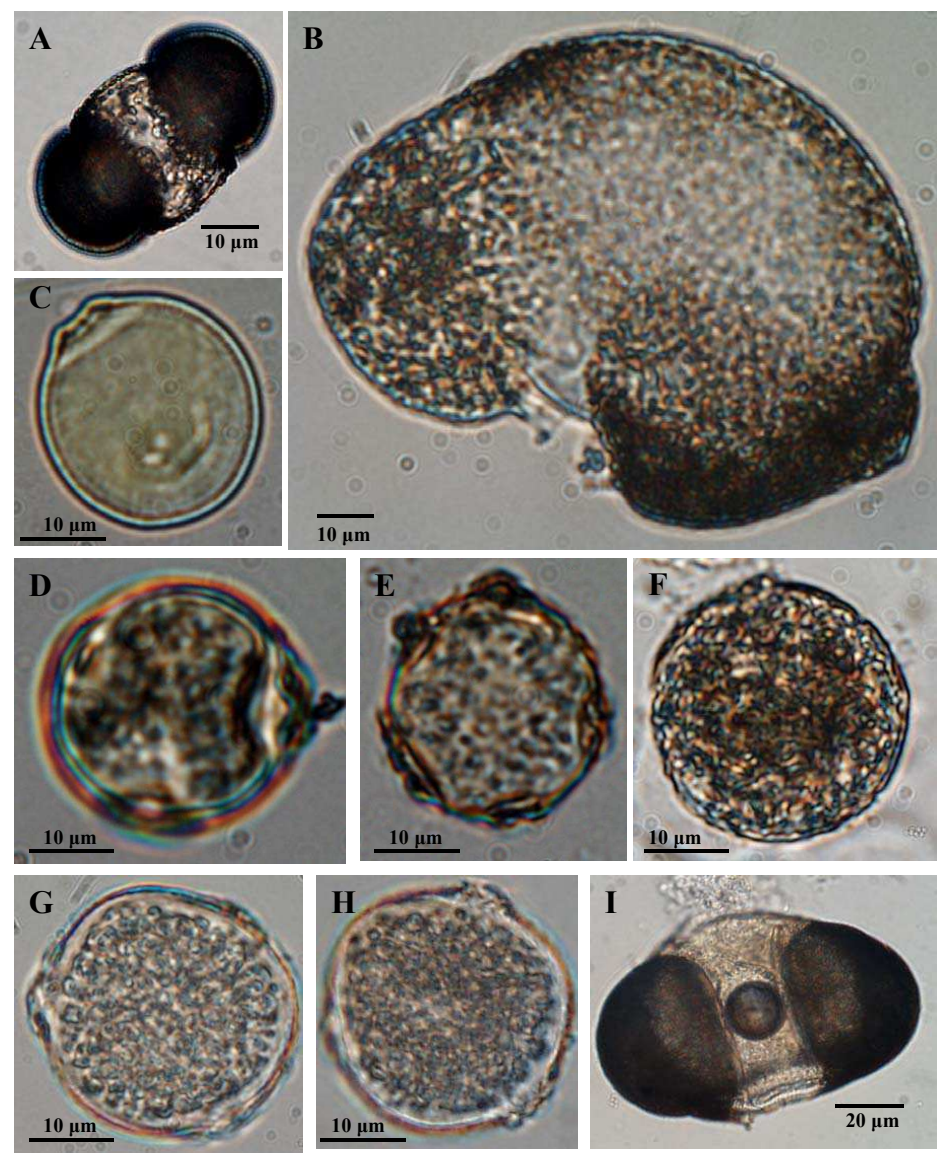

Fig. 5. Examples of photos of plant pollen grains from the high mountain snow from the Alps sampling sites: (A) - Pinus, (B) - Abies, (C) and (D) - Betula, (E) - Almus viridis, (F) Dicranoweisia grimmiacea and triporate pollen grain - (G), (H); and from the Andes Picea. (I).

\section{BGD}

4, 1779-1813, 2007

\section{Microbial \\ communities in} aerosol, snow and ice

J. Elster et al.

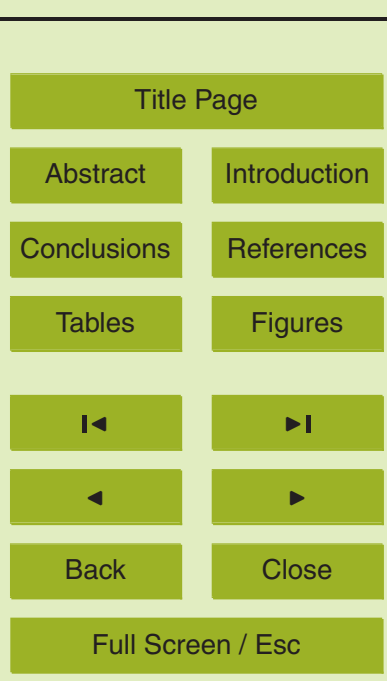

Printer-friendly Version

Interactive Discussion

EGU 
BGD

4, 1779-1813, 2007

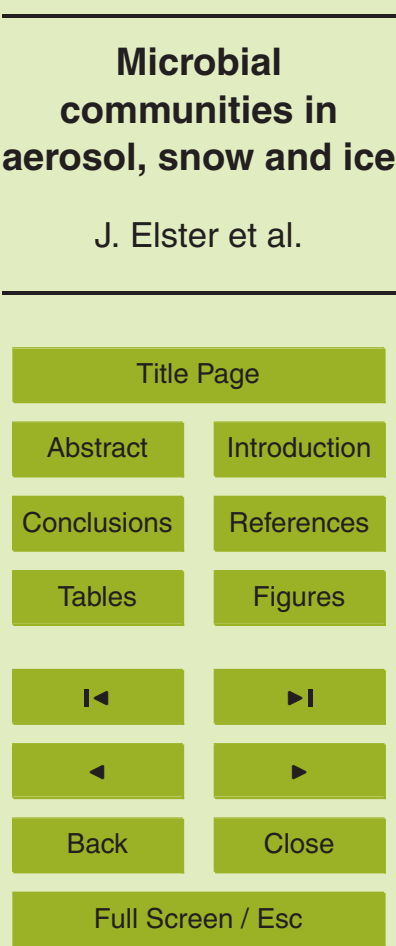

Printer-friendly Version

Interactive Discussion 